\title{
Resolving ecological feedbacks on the ocean carbon sink in Earth system models
}

\author{
David I. Armstrong McKay ${ }^{1,2}$, Sarah E. Cornell ${ }^{1,2}$, Katherine Richardson ${ }^{3}$, and Johan Rockström ${ }^{1,4}$ \\ ${ }^{1}$ Stockholm Resilience Centre, Stockholm University, Stockholm 106 91, Sweden \\ ${ }^{2}$ Bolin Centre for Climate Research, Stockholm University, Stockholm 106 91, Sweden \\ ${ }^{3}$ Globe Institute, Center for Macroecology, Evolution and Climate, \\ University of Copenhagen, Copenhagen 2100, Denmark \\ ${ }^{4}$ Potsdam Institute for Climate Impact Research, Potsdam 14473, Germany \\ Correspondence: David I. Armstrong McKay (david.armstrongmckay@su.se)
}

Received: 19 June 2020 - Discussion started: 15 July 2020

Revised: 30 April 2021 - Accepted: 17 May 2021 - Published: 14 July 2021

\begin{abstract}
The Earth's oceans are one of the largest sinks in the Earth system for anthropogenic $\mathrm{CO}_{2}$ emissions, acting as a negative feedback on climate change. Earth system models project that climate change will lead to a weakening ocean carbon uptake rate as warm water holds less dissolved $\mathrm{CO}_{2}$ and as biological productivity declines. However, most Earth system models do not incorporate the impact of warming on bacterial remineralisation and rely on simplified representations of plankton ecology that do not resolve the potential impact of climate change on ecosystem structure or elemental stoichiometry. Here, we use a recently developed extension of the cGEnIE (carbon-centric Grid Enabled Integrated Earth system model), ecoGEnIE, featuring a trait-based scheme for plankton ecology (ECOGEM), and also incorporate cGEnIE's temperature-dependent remineralisation (TDR) scheme. This enables evaluation of the impact of both ecological dynamics and temperaturedependent remineralisation on particulate organic carbon (POC) export in response to climate change. We find that including TDR increases cumulative POC export relative to default runs due to increased nutrient recycling $(+\sim 1.3 \%)$, whereas ECOGEM decreases cumulative POC export by enabling a shift to smaller plankton classes $(-\sim 0.9 \%)$. However, interactions with carbonate chemistry cause opposite sign responses for the carbon sink in both cases: TDR leads to a smaller sink relative to default runs $(-\sim 1.0 \%)$, whereas ECOGEM leads to a larger sink $(+\sim 0.2 \%)$. Combining TDR and ECOGEM results in a net strengthening of POC export $(+\sim 0.1 \%)$ and a net reduction in carbon sink $(-\sim 0.7 \%)$ relative to default. These results illustrate the degree to which ecological dynamics and biodiversity modulate the strength of the biological pump, and demonstrate that Earth system models need to incorporate ecological complexity in order to resolve non-linear climate-biosphere feedbacks.
\end{abstract}

\section{Introduction}

Oceans absorb about a quarter of anthropogenic carbon dioxide emissions, drawing down around $2-3 \mathrm{PgC} \mathrm{yr}^{-1}$ in recent decades (Ciais et al., 2013; Friedlingstein et al., 2019; Gruber et al., 2019). The mechanisms of carbon sink processes are well-understood: solubility (dissolution) and biological (soft tissue and hard carbonate) pumps transfer carbon to the deep ocean where it remains on timescales of several centuries to millennia (Broecker and Peng, 1982). However, increasing ocean temperature as a result of global warming could potentially lead to a weakening of this ocean carbon sink (Arora et al., 2013; Ciais et al., 2013). The global carbon sink uptake rate was observed to decline by $\sim 0.91 \% \mathrm{yr}^{-1}$ between 1959 and 2012; approximately $40 \%$ of this decline is estimated to have been due to feedback responses of sink processes (nonlinear carbon-cycle responses to $\mathrm{CO}_{2}$ and carbon-climate coupling), with the oceans playing a large role (Raupach et al., 2014). The combined effect of future feedbacks on both 
land and ocean carbon sinks reduce the RCP4.5-compatible anthropogenic carbon budget by $\sim 157 \pm 76 \mathrm{PgC}$ (RCP Representative Concentration Pathway; Ciais et al., 2013).

This sink weakening might therefore act as a positive feedback on anthropogenic warming (Steffen et al., 2018). However, many of the Earth system models (ESMs) used to make these carbon sink projections do not incorporate sufficient ecological complexity to fully resolve these feedbacks; for the ocean, these include the impact of both warming and acidification on metabolic dynamics, ecosystem structure, and nutrient stoichiometry (Ciais et al., 2013). Of the 10 ESMs from the Coupled Model Intercomparison Project Phase 5 (CMIP5) used for carbon sink projections in the fifth assessment report of the Intergovernmental Panel on Climate Change (IPCC AR5), only one resolves the impact of warming on organic carbon remineralisation, three resolve different plankton sizes, and three resolve changing nutrient usage ratios (discussed in Sect. 2), all of which critically influence the biological pump in a warming ocean. While there have been some improvements in the next-generation CMIP6 ESMs, most still use a fixed remineralisation parameterisation for exported organic carbon and feature broad size classes rather than a full spectrum of plankton size classes.

In this study, we investigate changes in the biological pump in response to climate change and ocean acidification using ecoGEnIE, an ESM of intermediate complexity (EMIC) with more complex biogeochemistry and ecosystem dynamics than present in most CMIP ESMs. The ecoGEnIE model allows temperature-dependent remineralisation, greater biodiversity via size-trait-based plankton ecology as well as flexible elemental stoichiometry. This combination allows the impact of metabolic and ecological dynamics on the biological pump and the ocean carbon sink in response to climate change to emerge, while the choice of an EMIC makes such additional complexity computationally tractable. We simulate a suite of historical and future climate change scenarios and assess the impact on the ocean carbon sink of replacing the default remineralisation parameterisation with the temperature-dependent scheme and/or the parameterised biogeochemistry module with ecoGEnIE's new explicit traitbased plankton ecology scheme.

This paper is structured as follows: in Sect. 2, we give detailed background on the role of the biological pump, how it may be affected by climate change and ocean acidification, and the extent to which current Earth system models resolve these effects; in Sect. 3, we describe the ecoGEnIE model and our experimental set-up; in Sect. 4, we describe the results of our experiments, focusing on the contrasting results for biological pump strength and the ocean carbon sink across the different model configurations; finally, in Sect. 5, we discuss the implications and limitations of our results.

\section{Background}

The primary driver of a weakening ocean carbon sink in response to anthropogenic climate change is the reduced $\mathrm{CO}_{2}$ dissolution capacity of warmer water (i.e. a weaker solubility pump), but changes in the biological pump modulate this physicochemical process by affecting the vertical partitioning of carbon within the ocean. In general, Earth system models project reduced export production (i.e. a weakening of the biological pump) as a result of ocean stratification reducing nutrient availability (Bopp et al., 2013), but a reduced efficacy of the biological pump due to increased marine bacterial respiration has also been suggested as an important factor in past warm episodes (Boscolo-Galazzo et al., 2018; John et al., 2014a; Olivarez Lyle and Lyle, 2006).

The biological pump describes the fixation and export of carbon and nutrients from the surface to the poorly ventilated deep ocean by biological activity. The vast majority of this organic matter is remineralised as it sinks and is later gradually returned in dissolved form to surface waters by ocean upwelling (Fig. 1). The formation and export of calcium carbonate shells (particulate inorganic carbon; PIC) also forms part of the biological pump, but hereafter we focus on the soft tissue biological pump as it is the dominant driver of surface carbon export (Dunne et al., 2007).

After organic carbon is fixed in the surface euphotic layer by phytoplankton and some is consumed by zooplankton, particulate organic matter (POM) begins to be remineralised by detritivorous bacteria as it falls through the water column as POM rain. Most POM is remineralised to dissolved carbon and nutrients within the epipelagic mixed layer $(\sim 0$ $200 \mathrm{~m}$ ), where the nutrients released are rapidly recycled into "regenerated" production (Dugdale and Goering, 1967), and in the mesopelagic zone ( 200-1000 m) below, but up to 4$12 \mathrm{PgC} \mathrm{yr}^{-1}$ of particulate organic carbon (POC) leaves the surface ocean (Ciais et al., 2013; Dunne et al., 2007; Henson et al., 2011, 2012; Mouw et al., 2016a). This remineralisation profile follows a power-law-like distribution, with a rapid geometric decline in export flux from the base of the mixed layer to a small asymptotic flux by $\sim 1000 \mathrm{~m}$. Once in the poorly ventilated deep ocean, the surviving POM (most of which is subsequently remineralised) remains on centennial to millennial timescales before being eventually returned to the surface by upwelling, while a tiny fraction of mostly recalcitrant POM is buried in sediment and so sequestered on geological timescales.

The simplified representation of plankton ecology and the biological pump shown in Fig. 1 forms the basis of many marine biogeochemical models, such as the onesize fixed-trait phytoplankton and zooplankton classes in the common NPZD (nutrient-phytoplankton-zooplanktondetritus) scheme (Friedrichs et al., 2007; Kwiatkowski et al., 2014). This approach misses many important biogeochemical processes though, prompting the development of "dynamic green ocean models" which introduce multiple plank- 


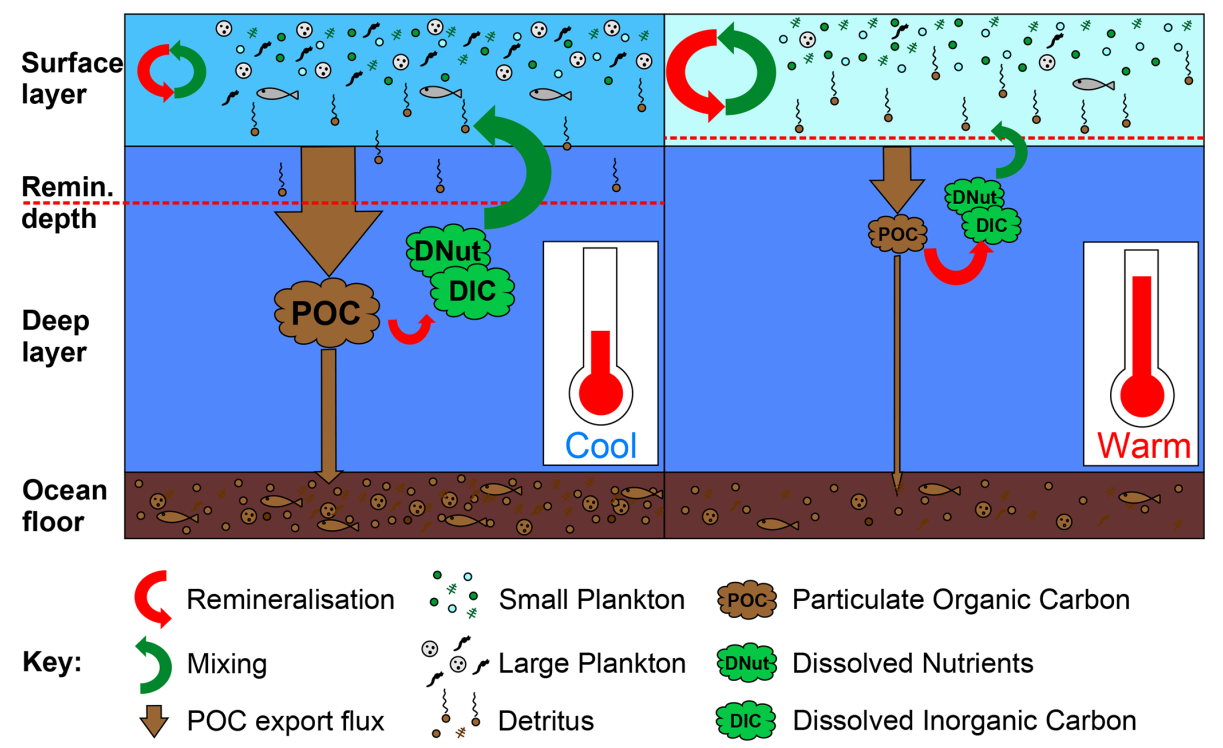

Figure 1. Schematic illustrating the impact of warming on the soft tissue biological pump. On the left side, under cooler pre-industrial conditions, cGEnIE's surface layer remains fairly well mixed with the deep ocean (green arrow), returning dissolved nutrients and carbon (DNut and DIC respectively) from the remineralisation of exported particulate organic carbon (POC; red arrow), while some POC is remineralised partly within the surface layer (surface red arrows). On the right side, warming leads to a shift to dominance by smaller plankton as well as stratification, leading to less mixing between the shallow and deep ocean, while shoaling of the remineralisation depth leads to greater recycling of nutrients and carbon close to the surface layer; these processes combine to result in an overall reduction in POC export and sedimentation and an overall increase in the residence time of nutrients and carbon in the ocean.

ton functional types (PFTs) with differentiated biogeochemical roles (Aumont et al., 2003; Quere et al., 2005). However, this class of plankton model is still limited by a profusion of poorly constrained parameters based on limited observations, taxonomic overspecificity, and the currently limited representation of biodiversity (Anderson, 2005; Boscolo-Galazzo et al., 2018; Friedrichs et al., 2007; Shimoda and Arhonditsis, 2016; Ward et al., 2018).

Although significant progress has been made since IPCC AR5 in optimising biogeochemical and ecological parameterisations in both NPZD and dynamic green ocean models using novel data assimilation and statistical techniques (Chien et al., 2020; Frants et al., 2016; Kriest, 2017; Kriest et al., 2020; Niemeyer et al., 2019; Sauerland et al., 2019; Schartau et al., 2017; Yao et al., 2019), neither approach fully accounts for allometric effects in biogeochemistry. Cell size distribution and elemental stoichiometry are dominant traits controlling plankton ecosystem function and total production (Finkel et al., 2010; Guidi et al., 2009), and projections indicate that the fraction of large phytoplankton will increase with nutrient availability and decrease with warming (Mousing et al., 2014). Plankton size also has a substantial effect on POC export efficiency, with observations and models suggesting that although smaller plankton favour a greater proportion of POC being exported from the surface layer, this POC, dominated by small, slow sinking particles, degrades more rapidly in the mesopelagic zone (Leung et al., 2021; Mouw et al., 2016b; Omand et al., 2020; Weber et al., 2016). Trait-based plankton models have been proposed to cover this allometric gap, based on simulating generic ecosystem rules using key functional traits such as size rather than specific taxonomic identity, allowing ecosystem structure, biodiversity, and biogeography to emerge without being parameterised (Bruggeman and Kooijman, 2007; Follows et al., 2007; Harfoot et al., 2014; McGill et al., 2006). These ecosystem models still do not enable better understanding of Earth system feedbacks though, as they have not been systematically incorporated into ESMs; thus, they do not capture wider biogeochemical and large-scale physical dynamics.

Most biogeochemical models feature fixed phytoplankton stoichiometry, often following the canonical Redfield ratio for $\mathrm{C}: \mathrm{N}: \mathrm{P}$ of $106: 16: 1$ or similar (Martiny et al., 2014; Redfield, 1934). However, real organisms can deviate substantially from this ratio, depending on cell size, functional group, and environmental conditions, with the Redfield ratio only emerging on a wider scale (Finkel et al., 2010). Climate change and ocean acidification are expected to substantially change ecosystem composition and nutrient availability, while increasing temperatures and $\mathrm{CO}_{2}$ concentrations have a direct impact on nutrient assimilation (Martiny et al., 2016; Moreno and Martiny, 2018; Riebesell et al., 2009). The $\mathrm{C}: \mathrm{P}$ ratio has also been observed to increase with decreasing $P$ availability as phytoplankton increase their $P$ usage efficiency, which could help maintain production and, therefore, export despite expansion of low-nutrient oligotrophic zones, or "oligotrophication" (Galbraith and Martiny, 2015). Thus, 
it is likely that stoichiometry of POC may change in response to ocean warming and acidification, with potential knock-on effects for the efficacy of the biological pump as a whole (Moreno et al., 2018). Despite this, flexible stoichiometry with nutrient uptake by phytoplankton depending on current availability and their current cell quota - is rarely incorporated in ocean biogeochemistry models (Ward et al., 2018).

Metabolic processes are also temperature dependent, with ocean temperature partly determining many marine biogeochemical patterns (Hoppe et al., 2002; Laws et al., 2000; Regaudie-De-Gioux and Duarte, 2012). For every $10^{\circ} \mathrm{C}$ increase in temperature, photosynthesis in any location is expected to increase by up to $100 \%$ (represented by a Q10 factor of 1-2), whereas average community respiration is expected to increase by between 100 and $200 \%(\mathrm{Q} 10=2-3)$ (Bendtsen et al., 2015; Boscolo-Galazzo et al., 2018; Eppley, 1972; Pomeroy and Wiebe, 2001; Regaudie-de-Gioux and Duarte, 2012; Sarmento et al., 2010). If warming-induced increases in respiration rates rise faster than production rates, organic matter will be remineralised more quickly, shoaling the remineralisation depth (the $e$-folding point at which $\sim$ $63 \%$ of POC is remineralised) (Boscolo-Galazzo et al., 2018; John et al., 2014a; Kwon et al., 2009) and may also reduce transfer efficiency within the mesopelagic zone (Fakhraee et al., 2020; Weber et al., 2016). One might expect this to reduce carbon export overall, as less carbon makes it out of the surface ocean, but increased remineralisation also allows more nutrients to be recycled back into the surface, potentially resulting in more regenerated production (Leung et al., 2021; Segschneider and Bendtsen, 2013; Taucher and Oschlies, 2011). Even a small shift in the remineralisation depth could have a significant potential impact on atmospheric $\mathrm{CO}_{2}$, potentially acting as a positive climate feedback mechanism. For example, a global deepening of $24 \mathrm{~m}$ of the $e$-folding depth (e.g. as a result of cooling) reduced $\mathrm{CO}_{2}$ by $10-27 \mathrm{ppm}$ in one model (Kwon et al., 2009). Although the biological pump itself does not act as a carbon sink when in long-term equilibrium (as exported carbon is returned to the surface by upwelling on millennial timescales), a change in biological pump strength would create a transient carbon sink if it enables accumulation of carbon in the deep ocean before a new equilibrium state is reached (Goodwin et al., 2008).

Other processes that affect the biological pump and remineralisation will also be impacted by climate change. Ocean stratification is projected to increase, as surface warming increases the temperature gradient (Ciais et al., 2013; Riebesell et al., 2009). This reduces the nutrient flux from deep to surface waters, potentially leading to oligotrophication in lower-latitude surface waters (Bopp et al., 2005; Sarmiento et al., 2004). Oligotrophication leads to lower overall productivity in productive regions, but warming will not substantially affect productivity in existing oligotrophic regions where production is already limited (Richardson and Bendtsen, 2017). Oligotrophic regions may also be more productive than expected due to continued subsurface production in deep chlorophyll maxima, but most ESMs do not resolve this phenomenon (Richardson and Bendtsen, 2019). The reduction in nutrient supply may also favour smaller plankton that can better cope with warmer and oligotrophic conditions, resulting in a shift in ecosystem dynamics and function (Beaugrand et al., 2010; Bopp et al., 2005; Finkel et al., 2010). Reduced mixing rates along with surface warming also result in ocean interior deoxygenation, leading to an expansion of oxygen minimum zones, reduced nitrogen availability due to increasing denitrification, and increased phosphate release from affected sediments (Ciais et al., 2013; Keeling et al., 2010; Stramma et al., 2008).

The organic biological pump may also be affected by ocean acidification through shifting ecosystem composition, altered nutrient availability, and stoichiometric effects (Ciais et al., 2013; Nagelkerken and Connell, 2015; Riebesell et al., 2009; Tagliabue et al., 2011). Acidification may increase the $\mathrm{C}: \mathrm{N}$ uptake ratio and decrease the $\mathrm{N}: \mathrm{P}$ uptake ratio, potentially making production more efficient (Riebesell et al., 2007; Tagliabue et al., 2011). Acidification could also lead to reduced particle ballasting (the hypothesised process by which denser falling PIC protects associated POC and increases POC export) by reducing the supply of PIC, resulting in reduced efficiency of POC export (Armstrong et al., 2001; Klaas and Archer, 2002). However, the overall effect of ocean acidification feedbacks remains uncertain (Doney et al., 2020), and many of these processes are not resolved by ESMs. Furthermore, the human-driven loss of organisms higher up the food chain as a result of overharvesting and habitat degradation has a considerable yet poorly quantified effect on the biological pump (Pershing et al., 2010). Many of these factors influence and/or are influenced by both the magnitude of primary production and the remineralisation depth.

Despite these known influences on the biological pump, many of the ESMs used for the IPCC AR5's ocean carbon sink projections incorporated few if any of these biogeochemical processes (Ciais et al., 2013; Schwinger et al., 2014). One study (Segschneider and Bendtsen, 2013) quantified the impact of including temperature-dependent remineralisation (TDR), modifying the CMIP5 model MPI-ESM and its marine biogeochemistry model HAMOCC5.2, and projected an $\sim 18 \mathrm{PgC}$ reduction in ocean carbon uptake by 2100 under high-emission scenario RCP8.5. However, only 1 out of 10 CMIP5 ESMs featured non-fixed POC remineralisation profiles by enabling TDR (CanESM2) (Table 1), with most instead prescribing a fixed attenuating remineralisation profile with vertical POC flux following modern ocean observations (sometimes called the "Martin Curve"; Bendtsen et al., 2015; Dunne et al., 2007; Martin et al., 1987). Additionally, NPZD-type models cannot fully resolve the potential impact of climate change or ocean acidification on ecosystem structure, biodiversity, and plankton size shifts, as they do not resolve allometric or stoichiometric effects. Only 4 of the 10 CMIP5 ESMs featured multiple PFTs with different ecosystem functions beyond a simple NPZD scheme. Of these, only 
Table 1. Features critical for resolving biological pump dynamics of CMIP5 ESMs used to simulate ocean carbon sink projections in IPCC AR5. Details are based on IPCC AR5 WG1 Tables 6.11 (Ciais et al., 2013), 9.A.1 (Flato et al., 2013), and cited literature. Note that there are some mismatches between number of functional groups reported in the literature and the IPCC description. Highlighted cells indicate the models with the most (bold font) or moderately (italic font) comprehensive - but not necessarily sufficient - representation of the relevant model feature. "Biogeo." refers to biogeochemical module, and "Inc." refers to inclusive (i.e. the ESM does not have a specific biogeochemical module, with biogeochemistry implicit in the ocean module instead).

\begin{tabular}{|c|c|c|c|c|c|c|c|c|c|c|}
\hline $\begin{array}{l}\text { ESM } \\
\text { (variant) }\end{array}$ & $\begin{array}{l}\text { Biogeo. } \\
\text { module }\end{array}$ & Key references & Type $^{\mathrm{a}}$ & $\begin{array}{l}\text { Functional } \\
\text { groups }^{b}\end{array}$ & $\begin{array}{l}\text { Remineral- } \\
\text { isation }^{c}\end{array}$ & $\begin{array}{l}\text { Element } \\
\text { cycles }^{d}\end{array}$ & $\begin{array}{l}\text { Elemental } \\
\text { stoichio- } \\
\text { metry }\end{array}$ & $\begin{array}{l}\text { Limiting } \\
\text { nutrient }^{f}\end{array}$ & $\begin{array}{l}\text { Shell } \mathrm{Si} \text { and } \\
\mathrm{Ca}^{\mathrm{g}}\end{array}$ & $\begin{array}{l}\text { Ballasting } \\
\text { option }^{\mathrm{h}}\end{array}$ \\
\hline $\begin{array}{l}\text { BCC- } \\
\text { CSM1.1 }\end{array}$ & (Inc.) & $\begin{array}{l}\text { Based on } \\
\text { OCMIP2 and MOM4; } \\
\text { Najjar et al. (2007); } \\
\text { Wu et al. (2014) }\end{array}$ & $\begin{array}{l}\text { Nutrient- } \\
\text { restoring }\end{array}$ & 0T: n/a [0] & Fixed rate & $\mathrm{C}, \mathrm{P}, \mathrm{O}$ & Fixed & $P$ & $\mathrm{n} / \mathrm{a}$ & $\mathrm{n} / \mathrm{a}$ \\
\hline $\begin{array}{l}\text { CESM1 } \\
(\mathrm{BGC})\end{array}$ & BEC & $\begin{array}{l}\text { Long et al. (2013); } \\
\text { Moore et al. (2013) }\end{array}$ & PFTs & $\begin{array}{l}\text { 4.5T: } \\
3.5 \mathrm{P} \\
\text { (diatom, } \\
\text { diaz., } \\
\text { small + cocco } \\
\text { fraction) } \\
1 \mathrm{Z}[4]\end{array}$ & $\begin{array}{l}\text { Fixed rate } \\
\text { (soft/ballast) }\end{array}$ & $\begin{array}{l}\text { C, N, P, } \\
\text { Fe, Si, O }\end{array}$ & $\begin{array}{l}\text { Fixed } \\
\text { quasi- } \\
\text { Redfield } \\
\text { (except } \\
\text { diaz.), Fe } \\
\text { quota }\end{array}$ & $\begin{array}{l}\text { N, P, Fe, } \\
\text { Si }\end{array}$ & $\begin{array}{l}\text { Diatoms } \\
\text { (Si) and } \\
\text { cocco. }(\mathrm{Ca}) \\
\text { separated } \\
\text { by classes }\end{array}$ & $\begin{array}{l}\text { Yes, part } \\
\text { of fixed } \\
\text { remin. } \\
\text { rate }\end{array}$ \\
\hline CanESM2 & CMOC & $\begin{array}{l}\text { Arora et al. (2009, } \\
2011) \text {; Christian et al. } \\
(2010)\end{array}$ & NPZD & $\begin{array}{l}\text { 2T: } 1 \mathrm{P} 1 \mathrm{Z} \\
{[1 \mathrm{X}]}\end{array}$ & TDR & $\mathrm{C}, \mathrm{N}$ & $\begin{array}{l}\text { Fixed - } \\
\text { Redfield }\end{array}$ & $\begin{array}{l}\mathrm{N}(\mathrm{Fe} \\
\text { paramete- } \\
\text { rised })\end{array}$ & $\begin{array}{l}\text { Temp.- } \\
\text { depend. rain } \\
\text { ratio for } \mathrm{Ca} \text {, } \\
\text { no } \mathrm{Si}\end{array}$ & $\begin{array}{l}\text { No men- } \\
\text { tion }\end{array}$ \\
\hline $\begin{array}{l}\text { GFDL- } \\
\text { ESM } \\
(2 \mathrm{G} \text { and } \\
2 \mathrm{M})\end{array}$ & TOPAZ2 & $\begin{array}{l}\text { Dunne et al. (2012, } \\
\text { 2013); Henson et } \\
\text { al. (2009) }\end{array}$ & PFTs & $\begin{array}{l}\text { 3.5T: 3P } \\
\text { (small, } \\
\text { large, } \\
\text { diaz.) 1Z } \\
\text { implicit } \\
{[6 \mathrm{X}]}\end{array}$ & $\begin{array}{l}\text { Fixed rate } \\
\text { (anoxic/oxic) }\end{array}$ & $\begin{array}{l}\text { C, N, P, } \\
\text { Fe, Si, O }\end{array}$ & $\begin{array}{l}\text { Variable } \\
\mathrm{N}: \mathrm{P}, \\
\text { optimal } \\
\text { alloca- } \\
\text { tion, P Fe } \\
\text { quota }\end{array}$ & $\begin{array}{l}\mathbf{N}+\mathbf{A m} \\
\mathbf{P}, \mathbf{F e}\end{array}$ & $\begin{array}{l}\text { No classes; } \\
\text { opal } \quad(\mathrm{Si}), \\
\text { calc., and } \\
\text { arag. } \quad(\mathrm{Ca}) \\
\text { "diag- } \\
\text { nosed" }\end{array}$ & Yes \\
\hline $\begin{array}{l}\text { HADGEM2 } \\
(\mathrm{CC} \text { and } \\
\mathrm{ES})\end{array}$ & $\begin{array}{l}\text { Diat- } \\
\text { HadOCC }\end{array}$ & $\begin{array}{l}\text { Collins et al. (2011); } \\
\text { Halloran (2012); Jones } \\
\text { et al. (2011); Palmer } \\
\text { and Totterdell (2001) }\end{array}$ & PFTs & $\begin{array}{l}3 T: \\
2 P \text { (non- } \\
\text { diatoms } / \text { di- } \\
\text { atoms) } 1 Z \\
{[3]}\end{array}$ & Fixed rate & $\begin{array}{l}\mathrm{C}, \mathrm{N}, \mathrm{Fe}, \\
\mathrm{Si}\end{array}$ & $\begin{array}{l}\text { Fixed - } \\
\text { Redfield }\end{array}$ & $\begin{array}{l}N, F e, \\
\text { Si (and } \\
\text { dimethyl } \\
\text { sulfide) }\end{array}$ & $\begin{array}{l}\text { Si and Ca } \\
\text { separated } \\
\text { as } \\
\text { diatom/non- } \\
\text { diatom } \\
\text { classes }\end{array}$ & $\begin{array}{l}\text { No men- } \\
\text { tion }\end{array}$ \\
\hline
\end{tabular}

\begin{tabular}{|c|c|c|c|c|c|c|c|c|c|c|}
\hline $\begin{array}{l}\text { INM- } \\
\text { CM4 }\end{array}$ & (Inc.) & Volodin (2007) & $\begin{array}{l}\text { Paramet- } \\
\text { erised } \\
\text { POC flux }\end{array}$ & 0T: n/a [0] & $\mathrm{n} / \mathrm{a}$ & $\mathrm{C}$ & $\mathrm{n} / \mathrm{a}$ & $\mathrm{n} / \mathrm{a}$ & $\mathrm{n} / \mathrm{a}$ & $\mathrm{n} / \mathrm{a}$ \\
\hline $\begin{array}{l}\text { IPSL- } \\
\text { CM5 } \\
\text { (A-LR, } \\
\text { A-MR, } \\
\text { and } \\
\text { B-LR) }\end{array}$ & PISCES & $\begin{array}{l}\text { Aumont et al. (2003); } \\
\text { Aumont and Bopp } \\
(2006) \text {; Dufresne et } \\
\text { al. (2013) }\end{array}$ & PFTs & $\begin{array}{l}4 \mathrm{~T}: 2 \mathrm{P} \\
\text { (diatom, } \\
\text { nano) } 2 \mathrm{Z} \\
\text { (micro, } \\
\text { meso) } \\
{[2 \mathrm{X}]}\end{array}$ & $\begin{array}{l}\text { Fixed rate } \\
\text { (anoxic/oxic) }\end{array}$ & $\begin{array}{l}\mathrm{C}, \mathrm{N}, \mathrm{P}, \\
\mathrm{Fe}, \mathrm{Si}\end{array}$ & $\begin{array}{l}\text { C, N, P } \\
\text { Redfield; } \\
\text { Fe Si } \\
\text { quota }\end{array}$ & $\begin{array}{l}\mathbf{N}+\mathbf{A m}, \\
\mathbf{P}, \mathrm{Fe}, \mathrm{Si}\end{array}$ & $\begin{array}{l}\text { Diatom Si } \\
\text { class; } \\
\text { ad hoc } \\
\text { parame- } \\
\text { terised rain } \\
\text { ratio for Ca }\end{array}$ & No \\
\hline $\begin{array}{l}\text { MIROC- } \\
\text { ESM } \\
\text { (- and } \\
\text { CHEM) }\end{array}$ & $\begin{array}{l}\text { (NPZD- } \\
\text { type) }\end{array}$ & $\begin{array}{l}\text { Kawamiya } \\
\text { al. et } \\
\text { tner et al. }(2000) \text { S } \\
\text { Watanabe et al. }\end{array}$ & NPZD & $\begin{array}{l}\text { 2T: } 1 \mathrm{P} 1 \mathrm{Z} \\
{[2]}\end{array}$ & Fixed rate & $\mathrm{C}, \mathrm{N}$ & $\begin{array}{l}\text { Fixed - } \\
\text { Redfield }\end{array}$ & $\mathrm{N}$ & $\mathrm{n} / \mathrm{a}$ & $\begin{array}{l}\text { No men- } \\
\text { tion }\end{array}$ \\
\hline $\begin{array}{l}\text { MPI- } \\
\text { ESM } \\
(\mathrm{LR})\end{array}$ & HAMOCC5 & Ilyina et al. (2013) & NPZD & $\begin{array}{l}\text { 2T: } 1 \mathrm{P} 1 \mathrm{Z} \\
{[2]}\end{array}$ & $\begin{array}{l}\text { Fixed rate } \\
\text { (anoxic/oxic) }\end{array}$ & $\begin{array}{l}\mathrm{C}, \mathrm{N}, \mathrm{P}, \\
\mathrm{Fe}, \mathrm{Si}\end{array}$ & $\begin{array}{l}\text { Fixed - } \\
\text { Redfield }\end{array}$ & $\mathbf{N}, \mathbf{P}, \mathbf{F e}$ & $\begin{array}{l}\mathrm{Si} \text { and } \mathrm{Ca} \\
\text { fraction- } \\
\text { ated by } \mathrm{Si} \\
\text { availability }\end{array}$ & $\begin{array}{l}\text { No men- } \\
\text { tion }\end{array}$ \\
\hline $\begin{array}{l}\text { NorESM1 } \\
\text { (ME) }\end{array}$ & HAMOCC5 & Tjiputra et al. (2013) & & & & & & & & \\
\hline
\end{tabular}

${ }^{\mathrm{a}}$ NPZD denotes nutrient phytoplankton zooplankton detritus pools; PFTs denote plankton functional types (diatoms, coccolithophores, etc.). ${ }^{\mathrm{b}} n \mathrm{~T}$ is the total number; $n \mathrm{P}$ is the number of phytoplankton types; $n \mathrm{Z}$ is the number of zooplankton types; $[n]$ is the number of plankton types from IPCC AR5.1 Table $6.11 ;[n \mathrm{X}]$ is the mismatch between cited literature and IPCC AR5.1 Table 6.11. "diaz." denotes diazotrophs;

"cocco." denotes coccolithophores. ${ }^{\mathrm{c}}$ Fixed rate denotes prescribed remineralisation profile for sinking POC (sometimes split by class); TDR denotes temperature-dependent remineralisation. ${ }^{\mathrm{d}}$ Major and minor nutrient cycles present. ${ }^{\mathrm{e}}$ Fixed denotes set ratio of $\mathrm{C}: \mathrm{N}: \mathrm{P}$ etc. (e.g. Redfield Ratio) in OM; variable/quota denotes OM can take up/store differing ratios of nutrient relative to C. ${ }^{\mathrm{f}}$ One major limiting nutrient (P or $\mathrm{N}$ ), co-limitation by both, and/or micronutrients (e.g. Fe) as well. "Am" denotes ammonium. ${ }^{\mathrm{g}}$ Silicifiers and calcifiers differentiated (by parameterisation or by functional classes). ${ }^{\mathrm{h}}$ Ballasting (OM sticks to sinking PIC) available as an option. "n/a" denotes not applicable (model type does not allow ballasting to be parameterised); "No mention" means that ballasting is not mentioned in the key references (implying ballasting is not available). 
three account for plankton size in some way, and only three featured at least partially flexible stoichiometry (e.g. nutrient quotas and optimal allocation) that allow potential changes in nutrient utilisation in response to changing environmental conditions to be resolved (Kwiatkowski et al., 2018; Moreno and Martiny, 2018).

The next generation of CMIP6 ESMs for IPCC AR6 are currently in the process of completion, so insufficient results were available for use for comparison in this study. These models show some improvements in these regards, with five models reporting an increase in the number of explicit or implicit PFT or bacteria classes, three models introducing more variable stoichiometry (although one model has instead reduced flexible stoichiometry), and two models introducing more than one sinking POC classes (Séférian et al., 2020). Despite these improvements, the CMIP6 models still only feature broad size classes rather than a full spectrum of plankton size classes, only three have fully flexible stoichiometry, and most still use a fixed remineralisation profile for exported POC. Investigating changes in the biological pump in response to the physical and chemical perturbations of climate change and ocean acidification therefore requires an ESM with more complex biogeochemistry and ecosystem dynamics than present in these ESMs.

\section{Methods}

\subsection{The cGEnIE model}

ecoGEnIE is an extension of cGEnIE - the carbon-centric Grid Enabled Integrated Earth system model, an EMIC based on a modular framework efficiently resolving ocean circulation, biogeochemistry, and optional deep-sea sediment that has been simplified to focus on long-term carbon cycle (Ridgwell et al., 2007; Ridgwell and Schmidt, 2010). cGEnIE has been used in many previous studies of climatecarbon cycle interactions in both modern (Tagliabue et al., 2016) and palaeo applications (Gibbs et al., 2016; John et al., 2014a; Meyer et al., 2016; Monteiro et al., 2012; Norris et al., 2013; Ridgwell and Schmidt, 2010). EMICs such as cGEnIE have lower spatio-temporal resolution than more comprehensive ESMs based on atmosphere-ocean general circulation models and so are limited in their physical realism, but they are also less computationally expensive and, thus, well suited for investigating more complex biogeochemical dynamics and performing efficient simulations of longer timescales or multiple scenarios (Claussen et al., 2002; Ward et al., 2018).

cGEnIE's climate model (C-GOLDSTEIN) features 3D reduced physics (frictional geostrophic, non-eddy resolving) ocean circulation model coupled to a 2D energymoisture balance model of the atmosphere and a dynamicthermodynamic sea ice model (Edwards and Marsh, 2005; Marsh et al., 2011). C-GOLDSTEIN is configured on a $36 \times 36$ equal area horizontal grid (each cell being $10^{\circ}$ in longitude and varying from $\sim 3.2^{\circ}$ to $19.2^{\circ}$ in latitude), and has
16 logarithmically spaced vertical layers and 96 time steps per year. The horizontal and vertical transport of heat, salinity, and biogeochemical tracers is calculated via a combined parameterisation for isoneutral diffusion and eddy-induced advection, and features a surface mixed-layer scheme (based on the seasonal thermocline model of Kraus and Turner, 1967). cGEnIE also features a comprehensive ocean biogeochemistry module (BIOGEM) with phosphorus (in the form of phosphate, $\mathrm{PO}_{4}$ ) and iron as the co-limiting nutrients (Ridgwell et al., 2007; Ridgwell and Schmidt, 2010; Ward et al., 2018). Organic matter production and export is parameterised in BIOGEM as a function of nutrient availability and following a fixed dissolved-to-particulate organic matter (DOM : POM) ratio, whereas $\mathrm{CaCO}_{3}$ production and export are parameterised by a saturation-state-dependent particulate inorganic-to-organic carbon (PIC : POC) rain ratio. By default, BIOGEM uses fixed remineralisation profiles similar to the Martin curve for the sinking labile fractions of both POC and PIC (Martin et al., 1987; Ridgwell et al., 2007) but includes an optional temperature-dependent remineralisation scheme which has previously been used to explore the biological pump in warm palaeo-oceans (John et al., 2014b). An updated calibration of this scheme which also couples TDR with temperature-dependent export production was also recently developed (Crichton et al., 2021) and is the version (cGEnIE.muffin v0.9.13) used in this paper.

\subsection{The ecoGEnIE extension}

The current cGEnIE version (cGEnIE.muffin) has recently been extended to ecoGEnIE (v.1.0) by incorporating a new scheme for plankton ecology (ECOGEM), replacing cGEnIE's implicit, flux-based parameterisation biogeochemistry module BIOGEM with an explicitly resolved and temperature-sensitive trait-based ecosystem module (Ward et al., 2018). In contrast to BIOGEM, biomass is now explicitly resolved, with each plankton population subject to ecophysiological processes including nutrient uptake (subject to quota saturation), photosynthesis and oxygen production (subject to light limitation, photoacclimation, and seasonal light attenuation within a variable mixed layer depth), predation (subject to prey-switching, prey refugia, and prey assimilation), and mortality. Many of these processes are temperature sensitive (nutrient uptake, photosynthesis, and predation) or size dependent (maximum photosynthetic and nutrient uptake rates, nutrient affinities, cell carbon quotas, maximum prey ingestion rates, and DOM fraction). In this configuration of ecoGEnIE (v.1.0) there are two plankton functional types (PFTs) available: phytoplankton (with nutrient uptake and photosynthetic traits enabled) and zooplankton (with predation traits enabled), with further classes such as calcifiers and silicifiers to be made available in future. As calcifiers are not explicitly represented, $\mathrm{CaCO}_{3}$ production and export is still controlled by a saturation-state-dependent ratio to POC export. Explicitly resolving biomass also intro- 
duces a lag between environmental forcing and ecosystem response, allowing seasonal cycles and transient behaviour in POC production and export to emerge (Galbraith et al., 2015).

As size is the dominant trait controlling plankton biogeochemical function and response to warming (Finkel et al., 2010; Mousing et al., 2014), each PFT is further split into eight size classes ranging from 0.6 to $1900 \mu \mathrm{m}$. Zooplankton graze on all potential prey subject to availability with an optimum predator: prey length ratio of 10 . This allows a better resolution of biodiversity within the model relative to models without size classes, with the ecosystem capable of shifting to a different structure in response to environmental forcing. ECOGEM also includes flexible stoichiometry rather than being fixed to the canonical Redfield ratio, allowing dynamic usage of nutrients in response to warming, ocean acidification, and nutrient availability to also be resolved (BoscoloGalazzo et al., 2018; Martiny et al., 2016; Moreno and Martiny, 2018). DOM production is explicit in ECOGEM, allowing a variable and plankton-size-dependent POM : DOM ratio, variations in which may have a significant impact on primary production in oligotrophic regions (Richardson and Bendtsen, 2017) and would result in reduced POM export with a shift to smaller plankton classes.

Although using an EMIC such as cGEnIE and ecoGEnIE allows for greater ecological resolution, it introduces different limitations. cGEnIE and ecoGEnIE have coarse spatial ( $36 \times 36$ equal area horizontal grid and 16 ocean layers) and temporal resolution (every $\sim 4 \mathrm{~d}$ for C-GOLDSTEIN, every $\sim 8 \mathrm{~d}$ for BIOGEM, and every $\sim 0.4 \mathrm{~d}$ for ECOGEM); hence, it is not able to fully resolve spatial circulation and ecological patterns, vertical POC distribution, or the dynamics that potentially link stratification and deep chlorophyll maxima in oligotrophic regions (Richardson and Bendtsen, 2017, 2019). Subtle differences in spatial resolution and physical framework representations can have a substantial impact on circulation patterns, which could affect plankton community structure and the residence time of exported nutrients and carbon (Pasquier and Holzer, 2016; Sinha et al., 2010). Currently only two PFTs are available in ecoGEnIE (phytoplankton and zooplankton, with PIC export set as saturation-state-dependent ratio of POC), limiting the extent to which hard pump dynamics involving calcifiers and silicifiers can emerge in our results. ecoGEnIE has not yet been fully recalibrated to the modern ocean and does not perform quite as well against observational data for key biogeochemical tracers (DIC - dissolved inorganic carbon, ALK - alkalinity, $\mathrm{PO}_{4}, \mathrm{O}_{2}$ ) as cGEnIE (Ward et al., 2018), but the results are still broadly similar (reproducing approximately $90 \%$ of the global variability in DIC; more than $70 \%$ for $\mathrm{PO}_{4}, \mathrm{O}_{2}$, and ALK; more than $50 \%$ for surface chlorophyll; and broadly capturing vertical distributions of these tracers). In this study, we focus primarily on the global biological pump response rather than its spatial patterns, and we are also particularly concerned with surface DIC and its relation to ocean carbon sink dynamics; therefore, this configuration is sufficient for this global analysis.

\subsection{Experimental set-up}

We assess the differing impacts of replacing cGEnIE's fixed profile remineralisation (FPR) parameterisation with its temperature-dependent remineralisation (TDR) scheme (John et al., 2014b; Crichton et al., 2021) and replacing cGEnIE's original parameterised biogeochemistry BIOGEM module (BIO) with ecoGEnIE's trait-based ECOGEM module (ECO) (Ward et al., 2018). We test each new element both separately and in combination, analysing four cGEnIE and ecoGEnIE configurations:

- BIO+FPR is cGEnIE with the default BIOGEM module (BIO) and the default fixed profile remineralisation scheme (FPR);

- BIO+TDR is cGEnIE with the default BIOGEM module (BIO) and the alternative temperature-dependent remineralisation scheme (TDR);

- ECO+FPR is ecoGEnIE, incorporating the trait-based ECOGEM module with flexible stoichiometry (ECO), and the default fixed profile remineralisation scheme (FPR);

- ECO+TDR is ecoGEnIE (ECO) and the alternative temperature-dependent remineralisation scheme (TDR).

We use the global POC export flux $\left(\mathrm{PgCyr}^{-1}\right)$ from the surface layer (fixed in cGEnIE and ecoGEnIE as the top $80.8 \mathrm{~m}$ of the ocean, compared with $\sim 100 \mathrm{~m}$ in some studies such as Martin et al., 1987) as our measure of biological pump strength and compare cumulative changes up to the year $2100 \mathrm{CE}$. We also quantify cumulative changes in the ocean carbon sink for each configuration through the air-tosea $\mathrm{CO}_{2}$ flux. We calculate cumulative changes in biological pump and ocean carbon sink capacity for the policy-relevant timescale of the 21st century CE (Table 2), but results are also shown up to $2500 \mathrm{CE}$ (Fig. 2).

Each configuration is run under its default published calibration (or a combination of published parameters for ECO+TDR) as well as configurations recalibrated to result in the same pre-industrial global biological pump strength (POC export of $\sim 7.5$ and PIC export of $\sim 1 \mathrm{PgC} \mathrm{yr}^{-1}$ ) and similar global mean total DIC, ALK, and surface DIC speciation relative to the BIO+FPR and observational data (see Table S1 and Figs. S1-S45 in the Supplement). The configurations were recalibrated to have as similar a carbon cycle as possible in order to make the results easily comparable across the configurations, and POC export was chosen as the primary calibration constraint as the main variable being analysed. However, some differences remain between the recalibrated configurations as well as with the observational 
Table 2. Simulated changes in POC export and air-to-sea $\mathrm{CO}_{2}$ flux by $2100 \mathrm{CE}$ under different climate scenarios (CMIP5 RCPs 3PD, 4.5, 6.0, and 8.5), illustrating the relative changes in biological pump strength and ocean carbon sink capacity respectively. Italicised values in parentheses represent the changes as percentages, as described by the parenthesised headings.

\begin{tabular}{|c|c|c|c|c|c|c|}
\hline \multirow{2}{*}{$\begin{array}{l}\text { Climate } \\
\text { scenario } \\
\text { (CMIP5 RCP) }\end{array}$} & \multirow{2}{*}{$\begin{array}{l}\text { Model } \\
\text { configuration }\end{array}$} & \multicolumn{3}{|c|}{ Biological pump strength } & \multicolumn{2}{|c|}{ Ocean carbon sink capacity } \\
\hline & & 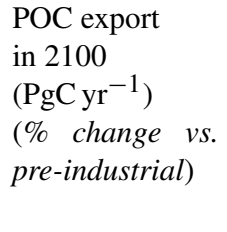 & $\begin{array}{l}\text { Cumulative } \\
\Delta \text { POC export } \\
\text { by } 2100 \text { relative } \\
\text { to pre-industrial } \\
\text { rates }(\mathrm{PgC})(\%)\end{array}$ & $\begin{array}{l}\text { Cumulative } \\
\Delta \text { POC } \\
\text { export by } 2100 \\
\text { relative to } \\
\text { BIO+FPR } \\
(\mathrm{PgC})(\%)\end{array}$ & $\begin{array}{l}\text { Cumulative } \\
\text { air-to-sea } \mathrm{CO}_{2} \\
\text { transfer by } 2100 \\
(\mathrm{PgC})(\% \text { in } \\
\text { ocean vs. total })\end{array}$ & $\begin{array}{l}\text { Cumulative } \\
\text { air-to-sea } \mathrm{CO}_{2} \\
\text { transfer by } \\
2100 \text { relative } \\
\text { to } \mathrm{BIO}+\mathrm{FPR} \\
(\mathrm{PgC})(\%)\end{array}$ \\
\hline \multirow{4}{*}{$\begin{array}{l}3 \mathrm{PD} \text { (low } \\
\text { warming, } \\
1.8^{\circ} \mathrm{C} \text { by } \\
2100)\end{array}$} & $\mathrm{BIO}+\mathrm{FPR}$ & $\begin{array}{r}7.20 \\
(-4.2 \%)\end{array}$ & $\begin{array}{r}-35.59 \\
(-1.4 \%)\end{array}$ & $\begin{array}{r}0 \\
(0 \%)\end{array}$ & $\begin{array}{r}450.1 \\
(52.4 \%\end{array}$ & $\begin{array}{r}0 \\
(0 \%)\end{array}$ \\
\hline & $\mathrm{BIO}+\mathrm{TDR}$ & $\begin{array}{r}8.15 \\
(+1.2 \%)\end{array}$ & $\begin{array}{r}-2.86 \\
(-0.1 \%)\end{array}$ & $\begin{array}{r}+32.72 \\
(+1.2 \%)\end{array}$ & $\begin{array}{r}445.6 \\
(51.9 \%)\end{array}$ & $\begin{array}{r}-4.52 \\
(-1.0 \%)\end{array}$ \\
\hline & $\mathrm{ECO}+\mathrm{FPR}$ & $\begin{array}{r}10.74 \\
(-5.3 \%)\end{array}$ & $\begin{array}{r}-66.60 \\
(-1.7 \%)\end{array}$ & $\begin{array}{r}-31.02 \\
(-0.8 \%)\end{array}$ & $\begin{array}{r}451.8 \\
(52.6 \%)\end{array}$ & $\begin{array}{r}+1.75 \\
(+0.4 \%)\end{array}$ \\
\hline & $\mathrm{ECO}+\mathrm{TDR}$ & $\begin{array}{r}10.84 \\
(-1.5 \%)\end{array}$ & $\begin{array}{r}-29.86 \\
(-0.8 \%)\end{array}$ & $\begin{array}{r}+5.72 \\
(+0.2 \%)\end{array}$ & $\begin{array}{r}447.6 \\
(52.1 \%)\end{array}$ & $\begin{array}{r}-2.51 \\
(-0.6 \%)\end{array}$ \\
\hline \multirow{4}{*}{$\begin{array}{l}4.5 \\
\text { (moderate } \\
\text { warming, } \\
2.6^{\circ} \mathrm{C} \text { by } \\
2100 \text { ) }\end{array}$} & $\mathrm{BIO}+\mathrm{FPR}$ & $\begin{array}{r}7.05 \\
(-6.1 \%)\end{array}$ & $\begin{array}{r}-40.57 \\
(-1.6 \%)\end{array}$ & $\begin{array}{r}0 \\
(0 \%)\end{array}$ & $\begin{array}{r}568.4 \\
(44.3 \%)\end{array}$ & $\begin{array}{r}0 \\
(0 \%)\end{array}$ \\
\hline & $\mathrm{BIO}+\mathrm{TDR}$ & $\begin{array}{r}8.10 \\
(+0.6 \%)\end{array}$ & $\begin{array}{r}-5.56 \\
(-0.2 \%)\end{array}$ & $\begin{array}{r}+35.01 \\
(+1.3 \%)\end{array}$ & $\begin{array}{r}562.7 \\
(43.9 \%)\end{array}$ & $\begin{array}{r}-5.70 \\
(-1.0 \%)\end{array}$ \\
\hline & $\mathrm{ECO}+\mathrm{FPR}$ & $\begin{array}{r}10.49 \\
(-7.5 \%) \\
\end{array}$ & $\begin{array}{r}-74.89 \\
(-2.0 \%) \\
\end{array}$ & $\begin{array}{r}-34.32 \\
(-0.9 \%) \\
\end{array}$ & $\begin{array}{r}569.8 \\
(44.4 \%)\end{array}$ & $\begin{array}{r}+1.37 \\
(+0.2 \%)\end{array}$ \\
\hline & $\mathrm{ECO}+\mathrm{TDR}$ & $\begin{array}{r}10.70 \\
(-2.7 \%)\end{array}$ & $\begin{array}{r}-35.34 \\
(-1.0 \%)\end{array}$ & $\begin{array}{r}+5.23 \\
(+0.1 \%)\end{array}$ & $\begin{array}{r}564.5 \\
(44.0 \%)\end{array}$ & $\begin{array}{r}-3.92 \\
(-0.7 \%)\end{array}$ \\
\hline \multirow{4}{*}{$\begin{array}{l}6.0 \quad \text { (high } \\
\text { warming, } \\
3.2^{\circ} \mathrm{C} \text { by } \\
2100 \text { ) }\end{array}$} & $\mathrm{BIO}+\mathrm{FPR}$ & $\begin{array}{r}6.94 \\
(-7.5 \%)\end{array}$ & $\begin{array}{r}-42.16 \\
(-1.7 \%)\end{array}$ & $\begin{array}{r}0 \\
(0 \%)\end{array}$ & $\begin{array}{r}641.6 \\
(38.0 \%)\end{array}$ & $\begin{array}{r}0 \\
(0 \%)\end{array}$ \\
\hline & $\mathrm{BIO}+\mathrm{TDR}$ & $\begin{array}{r}8.03 \\
(-0.2 \%)\end{array}$ & $\begin{array}{r}-7.02 \\
(-0.3 \%)\end{array}$ & $\begin{array}{r}+35.13 \\
(+1.3 \%)\end{array}$ & $\begin{array}{r}635.3 \\
(37.6 \%)\end{array}$ & $\begin{array}{r}-6.30 \\
(-1.0 \%)\end{array}$ \\
\hline & $\mathrm{ECO}+\mathrm{FPR}$ & $\begin{array}{r}10.31 \\
(-9.1 \%)\end{array}$ & $\begin{array}{r}-77.37 \\
(-2.0 \%)\end{array}$ & $\begin{array}{r}-35.21 \\
(-0.9 \%)\end{array}$ & $\begin{array}{r}642.5 \\
(38.0 \%)\end{array}$ & $\begin{array}{r}+0.89 \\
(+0.1 \%)\end{array}$ \\
\hline & ECO+TDR & $\begin{array}{r}10.57 \\
(-3.9 \%)\end{array}$ & $\begin{array}{r}-37.59 \\
(-1.0 \%)\end{array}$ & $\begin{array}{r}+4.57 \\
(+0.1 \%)\end{array}$ & $\begin{array}{r}636.7 \\
(37.7 \%)\end{array}$ & $\begin{array}{r}-4.93 \\
(-0.8 \%)\end{array}$ \\
\hline \multirow{4}{*}{$\begin{array}{l}8.5 \text { (severe } \\
\text { warming, } \\
4.2^{\circ} \mathrm{C} \text { by } \\
2100 \text { ) }\end{array}$} & $\mathrm{BIO}+\mathrm{FPR}$ & $\begin{array}{r}6.77 \\
(-9.8 \%)\end{array}$ & $\begin{array}{r}-48.63 \\
(-1.9 \%)\end{array}$ & $\begin{array}{r}0 \\
(0 \%)\end{array}$ & $\begin{array}{r}766.3 \\
(31.5 \%)\end{array}$ & $\begin{array}{r}0 \\
(0 \%)\end{array}$ \\
\hline & $\mathrm{BIO}+\mathrm{TDR}$ & $\begin{array}{r}7.98 \\
(-0.8 \%)\end{array}$ & $\begin{array}{r}-10.27 \\
(-0.4 \%)\end{array}$ & $\begin{array}{r}+38.36 \\
(+1.4 \%)\end{array}$ & $\begin{array}{r}758.7 \\
(31.2 \%)\end{array}$ & $\begin{array}{r}-7.64 \\
(-1.0 \%)\end{array}$ \\
\hline & $\mathrm{ECO}+\mathrm{FPR}$ & $\begin{array}{r}10.00 \\
(-11.8 \%)\end{array}$ & $\begin{array}{r}-88.45 \\
(-2.3 \%)\end{array}$ & $\begin{array}{r}-39.82 \\
(-1.0 \%)\end{array}$ & $\begin{array}{r}767.3 \\
(31.6 \%)\end{array}$ & $\begin{array}{r}+0.99 \\
(+0.1 \%)\end{array}$ \\
\hline & $\mathrm{ECO}+\mathrm{TDR}$ & $\begin{array}{r}10.40 \\
(-5.4 \%)\end{array}$ & $\begin{array}{r}-44.69 \\
(-1.2 \%)\end{array}$ & $\begin{array}{r}+3.94 \\
(+0.1 \%)\end{array}$ & $\begin{array}{r}760.2 \\
(31.3 \%)\end{array}$ & $\begin{array}{r}-6.15 \\
(-0.8 \%)\end{array}$ \\
\hline
\end{tabular}




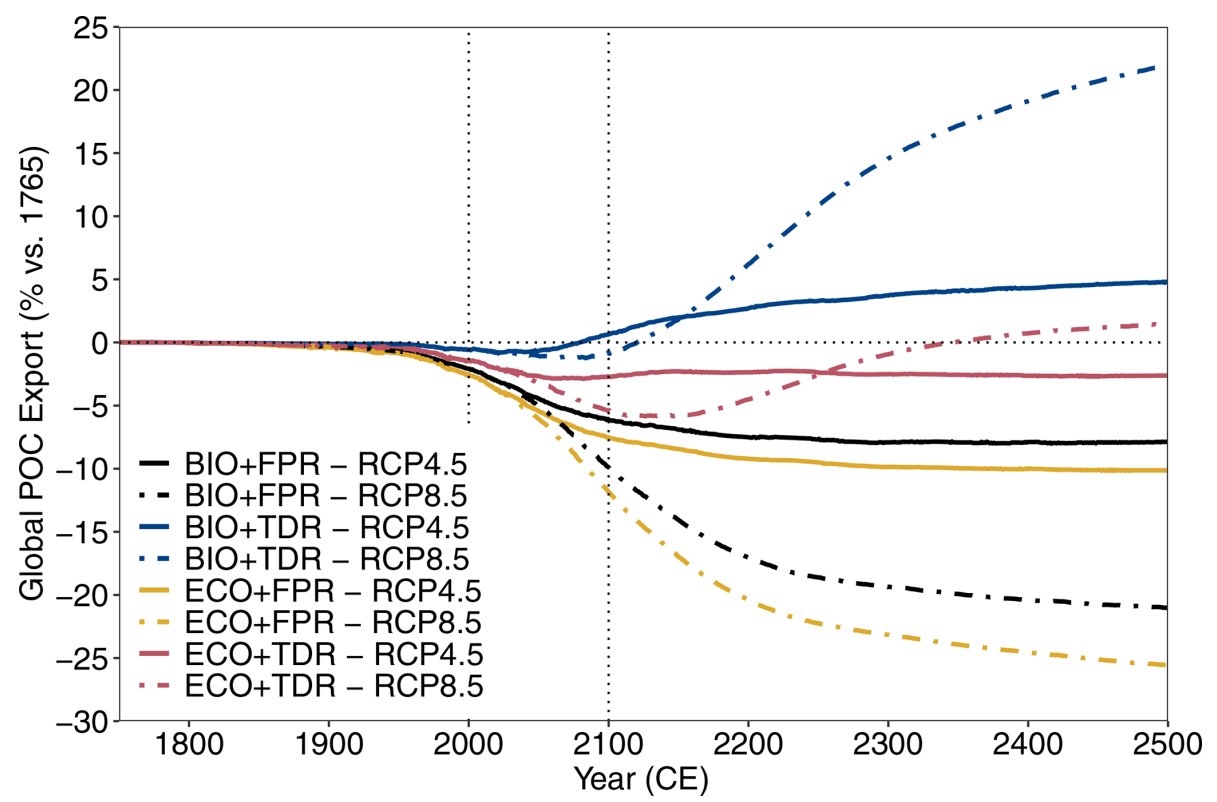

Figure 2. cGEnIE and ecoGEnIE simulation results for global POC export flux under different configurations and forcing scenarios. Results for RCP4.5 (solid lines) and RCP8.5 (dot-dashed lines) are shown for each of the configurations (BIO+FPR - black; BIO+TDR - blue; ECO+FPR - yellow; ECO+TDR - red), and the baseline POC export and the 21 st century are marked by the horizontal and vertical dotted lines respectively. Results for all emission scenarios are shown in Fig. S48 in the Supplement.

data. The main difference is higher POC and PIC sedimentation rates in the recalibrated ECO configurations as a result of specifying a higher recalcitrant $\mathrm{POC}$ fraction (from $\sim 5 \%$ to $\sim 32 \%-35 \%$ ) and higher PIC : POC ratio (from $4.85 \%$ to $\sim 5 \%$ ). This recalcitrant $\mathrm{POC}$ fraction and the resulting rain rate is unrealistically high compared with observations, but was necessary in order to respectively counter much higher POC export and lower PIC export in ecoGEnIE. In cGEnIE, recalcitrant POC remains inert until sedimentation and does not directly interact with the rest of the carbon cycle; in sediment-module-disabled configurations of cGEnIE, POC and PIC rain is returned as deep ocean DIC, ALK, and nutrients upon reaching the sea floor, meaning total ocean DIC is still conserved. Although biological pump perturbations on sub-overturning timescales $(<500-1000$ years $)$ will not significantly affect surface DIC via upwelled deep water within that time, a higher recalcitrant fraction would increase the average lifetime of regenerated DIC and nutrients in the ocean and gradually reduce the nutrient supply to the surface from intermediate waters. Optimising for equivalent POC export also leads to the surface carbonate concentration $\left(\left[\mathrm{CO}_{3}\right]\right)$ being reduced in the BIO+TDR recalibration compared with the default calibration, leading to a reduced carbonate buffer for the ocean carbon sink in these runs. In this paper, we focus on the results of default calibrations; however, in order to explore the mechanisms driving differences between the configuration responses and to constrain the impact of differing biological pump baselines, we also present the recalibra- tion results in the Supplement and discuss the differences in Sect. 4.

Each model configuration is spun up for 10000 years and restarted at $0 \mathrm{CE}$ (10 000 Holocene era, HE), and then forced in emissions mode from $1765 \mathrm{CE}$ with combined historical and future CMIP5 RCP total $\mathrm{CO}_{2}$ emission scenarios (3PD, $4.5,6.0$, and 8.5, corresponding to low-, moderate-, high-, and severe-emission scenarios respectively; 3PD is used instead of RCP2.6 to allow for long-term simulation beyond $2100 \mathrm{CE}$ ) extended through to $2500 \mathrm{CE}$ in order to assess multi-centennial dynamics (Meinshausen et al., 2011).

\section{Results}

\subsection{Physical climate response}

In its default configuration (BIO+FPR), cGEnIE projects surface air temperature warming of $1.8,2.6,3.2$, and $4.2^{\circ} \mathrm{C}$ by 2100 relative to $1850-1900$ in RCPs 3PD, 4.5, 6.0, and 8.5 respectively, which compares favourably with CMIP5 projections for these scenarios $(1.6 \pm 0.4,2.4 \pm 0.5,2.8 \pm 0.5$, and $4.3 \pm 0.7^{\circ} \mathrm{C}$ ) (Collins et al., 2013). In the ocean, cGEnIE$\mathrm{BIO}+\mathrm{FPR}$ projects sea surface warming of $1.2,1,8,2.1$, and $2.8^{\circ} \mathrm{C}$ by 2100 in RCPs 3PD, 4.5, 6.0, and 8.5 respectively (see Fig. S46 in the Supplement for spatial patterns of warming in RCP4.5). This can be compared to 0.6 and $2.0^{\circ} \mathrm{C}$ warming in the top $100 \mathrm{~m}$ in CMIP5 for RCPs 2.6 and 8.5 , with the apparent bias towards greater warming in cGEnIE reflecting the narrower surface layer $(80.8 \mathrm{~m})$ vs. the CMIP5 assessment. For baselines, cGEnIE's (BIO+FPR) 
pre-industrial surface air temperature (SAT) global baseline (1850-1900) is $\sim 12.5^{\circ} \mathrm{C}$, and the pre-industrial sea surface temperature (SST) global baseline is $\sim 18.8^{\circ} \mathrm{C}$, both of which also lie within the CMIP5 range (SAT towards the lower end, and SST at the higher end) (see Fig. S47 in the Supplement for spatial patterns of pre-industrial warmth in RCP4.5). The model's circulation responses are almost identical across the experiments, with only marginal differences in warming $\left(<\sim 0.01{ }^{\circ} \mathrm{C}\right.$ differences in ocean temperature for RCP4.5) between the scenarios across the configurations.

\subsection{Biological pump strength}

Our results show that the biological pump weakens by $2100 \mathrm{CE}$ under most scenarios and configurations, but adding TDR and trait-based plankton ecology with flexible stoichiometry has strong and opposite impacts on relative biological pump strength.

Under the default cGEnIE configuration (BIO+FPR), anthropogenic climate change results in an overall weakening of the biological pump, with global POC flux falling below pre-industrial levels by 2100 CE by $\sim 6.1 \%$ under RCP 4.5 and $\sim 9.8 \%$ under RCP8.5 (Table 2; Figs. 2 and S48 in the Supplement). This is in line with past projections of a $7.2 \%$ decline in surface POC export under SRES A2 (warming levels between RCPs 6.0 and 8.5) during the 21st century in an EMIC with an NPZD biogeochemistry module (Taucher and Oschlies, 2011), and a selection of CMIP5 ESMs declining by between $\sim 9$ and $\sim 20 \%$ under RCP 8.5 during the 21 st century with greater declines in models resolving dynamic plankton size classes and in the lower latitudes (Bopp et al., 2013; Cabré et al., 2015; Fu et al., 2016). In cGEnIE, this is primarily driven by stratification resulting in reduced surface nutrient concentrations and decreased primary production in high-productivity low- and mid-latitude waters (Fig. 3a), in line with previous model results (Bopp et al., 2005; Ciais et al., 2013; Crichton et al., 2021; Riebesell et al., 2009; Sarmiento et al., 2004), along with reduced nutrient supply to the North Atlantic and eastern Arctic due to overturning circulation slowdown. In contrast, there is an increase in production in high-latitude waters, where the mixed layer is already so much deeper than cGEnIE's surface layer (mostly $\gg 100 \mathrm{~m}$, vs. cGEnIE's $\sim 81 \mathrm{~m}$ surface layer; Fig. S49 in the Supplement) that stratification actually increases productivity by more effectively confining nutrients within cGEnIE's surface layer. This partially matches theoretical expectations in which stratification drives increased polar productivity by confining phytoplankton within the euphotic zone (Riebesell et al., 2009), but the mechanism driving this effect in cGEnIE is different as plankton are confined to the surface layer.

Adding TDR (BIO+TDR) leads to a substantially different result than the default cGEnIE configuration with a far smaller biological pump weakening that eventually reverses by the late 21 st or early 22 nd century, resulting in an overall $\sim 0.6 \%$ increase in POC export under RCP4.5 and a $\sim 0.8 \%$ decline under RCP8.5 by 2100 CE (Fig. 2). This might be expected to be because TDR results in an initial decrease in biological pump strength with warming as more POC is remineralised within the surface layer, which also leads to a shallower remineralisation depth and an increase in nutrient recycling and regenerated production in the surface layer. However, in this model POC remineralisation only occurs below the surface layer, and so regenerated production is not directly represented. Furthermore, observations show that while an increase in nutrient recycling within the surface layer can lead to an increase in production by reducing nutrient loss, it does not directly lead to an increase in export as well, as it is the reduction in export driving the increase in production. Only a new allochthonous source of nutrients to the surface layer would allow sustained increases in both production and export (Dugdale and Goering, 1967; Laws, 1991; Laws et al., 2000).

In our results, the shoaling of the remineralisation depth increases $\mathrm{PO}_{4}$ concentrations in the layers below the productive surface (cGEnIE layers 2-3, 81-283 m) from remineralisation that would otherwise have occurred deeper in intermediate waters (Fig. S50 in the Supplement). This, in turn, leads to increased allochthonous $\mathrm{PO}_{4}$ input to the surface layer through mixing, which is sufficient to lead to an elevated baseline in new production and POC export in warmer lower-latitude waters (and conversely lower baseline POC export in cooler mid-latitudes; Fig. 4a), and with warming counters the decline in POC export in the low and mid-latitudes observed in BIO+FPR (Fig. 3b). This result is consistent with previous modelling, which has shown that shoaling of the remineralisation depth in a common biogeochemical model leads to increased POC export (Kwon et al., 2009), and that including TDR in an EMIC resulted in increased net primary production and a marginally smaller decrease in POC export under RCP8.5 (Taucher and Oschlies, 2011). A recent update to cGEnIE's TDR scheme (Crichton et al., 2021) also found a similar result, with historical warming resulting in a $\sim 0.3 \%$ decline in POC export with TDR activated vs. $\sim 2.9 \%$ without. In contrast, at higher latitudes, including TDR leads to a lower baseline POC export than with FPR (Fig. 4a), as colder waters result in a deep remineralisation depth and less $\mathrm{PO}_{4}$ returned to the surface layer.

Activating ecoGEnIE (ECO+FPR) instead of TDR results in a greater weakening of the biological pump than in BIO+FPR, with global POC flux falling by $\sim 7.5 \%$ by 2100 CE under RCP4.5 and $11.8 \%$ under RCP8.5 (Fig. 2). Adding ECOGEM allows an overall decrease in average plankton size in response to climate change (Fig. S51 in the Supplement), as warming and stratification leads to oligotrophication in lower-latitude waters which favours smaller plankton size classes, and is in line with previous observational and modelling studies (Finkel et al., 2010; Riebesell et al., 2009). Smaller taxa produce more DOM than POM (Finkel et al., 2010); thus, the shift to smaller plankton classes in warmer regions decreases overall baseline POC 


\section{Pre-industrial baseline}

(a) BIO+FPR

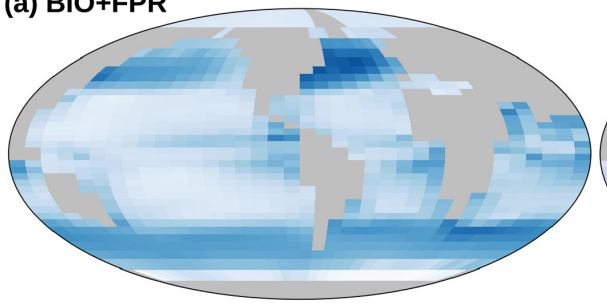

(b) BIO+TDR

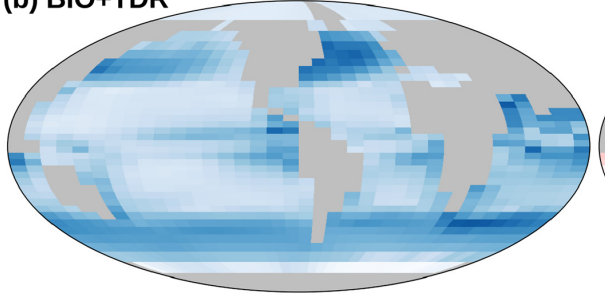

(c) ECO+FPR

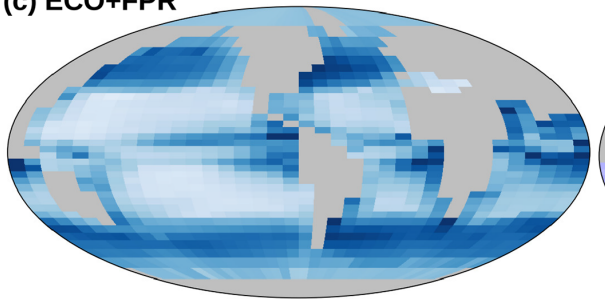

(d) ECO+TDR
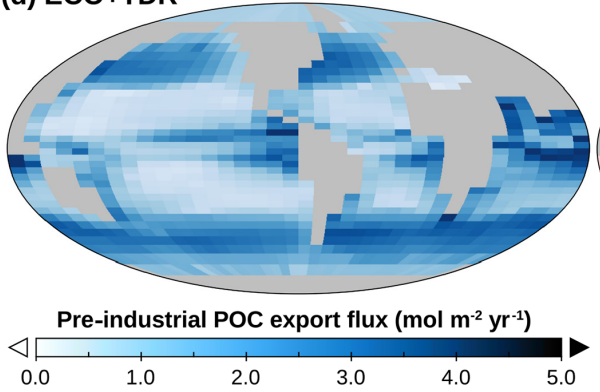

Change by 2100
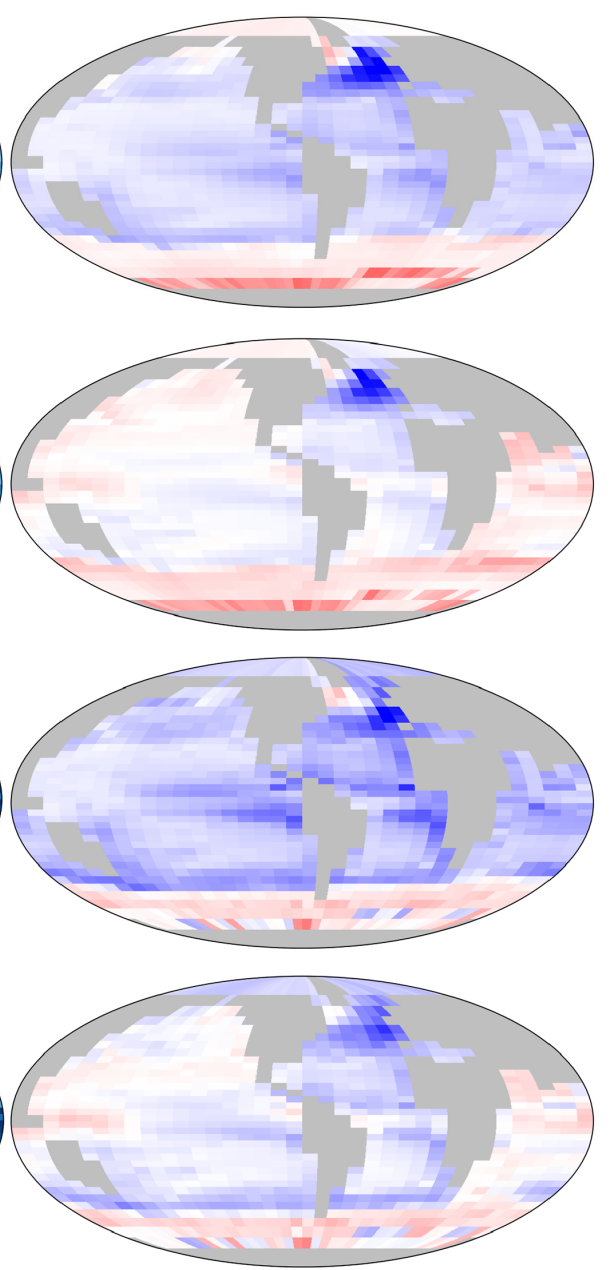

Change in POC export flux by $2100\left(\mathrm{~mol} \mathrm{~m}^{-2} \mathrm{yr}^{-1}\right)$

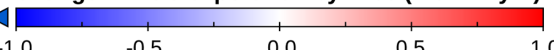

Figure 3. (a) cGEnIE and ecoGEnIE POC export maps for default calibrations of BIO+FPR (a), BIO+TDR (b), ECO+FPR (c), and ECO+TDR (d), showing baseline export patterns (left) and the change in POC export by 2100 relative to the 1765 pre-industrial baseline as a result of RCP4.5 (right). Plot created with Panoply, available from NASA Goddard Space Flight Center.

and PIC export (Fig. 4b), which accentuates the reduction in export due to stratification-induced nutrient and biomass decline in the low and mid-latitudes (Figs. 3c and S52 in the Supplement). This decline is sufficient to counteract the negative feedback of the shift to smaller particles increasing surface nutrient recycling due to shallower remineralisation (Leung et al., 2021). Activating ECOGEM also enables flexible stoichiometry, but the effect of this is difficult to disentangle from that of multiple size classes as well. However, some patterns and trends can be seen. The pre-industrial POM export C : $\mathrm{P}$ ratio lies above the standard Redfield ratio of 106:1 across most of the ocean outside the Southern Ocean, reaching $\sim 200: 1$ in equatorial upwelling regions, and the global mean closely matches recent observations of 163: 1 (Fig. S53 in the Supplement) (Martiny et al.,
2014). By 2100 CE this ratio increases across almost the entire ocean, especially along the Antarctic Polar Front and in the Arctic Ocean (Fig. S54 in the Supplement). This indicates that the amount of carbon exported for every unit of phosphorus increases with warming in response to stratification, partly ameliorating the decline in carbon export.

Without stratification and nutrient restriction, higher equilibrium temperatures in a previous ecoGEnIE study were associated with higher export production and mean cell size despite lower overall biomass (Wilson et al., 2018). Although increased phytoplankton nutrient usage (which is temperature dependent in ecoGEnIE) boosted small phytoplankton production in their study, this increase was assimilated by zooplankton grazing (which is also temperature dependent). This allowed larger phytoplankton to compete against small 
Default calibration

(a) BIO+TDR

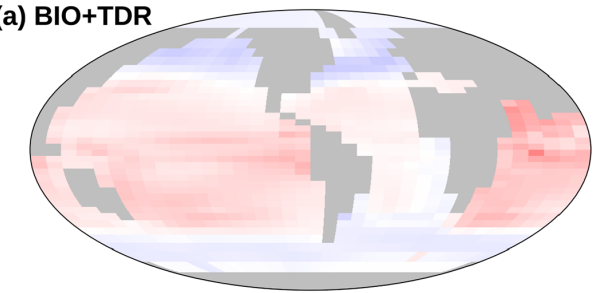

(b) ECO+FPR

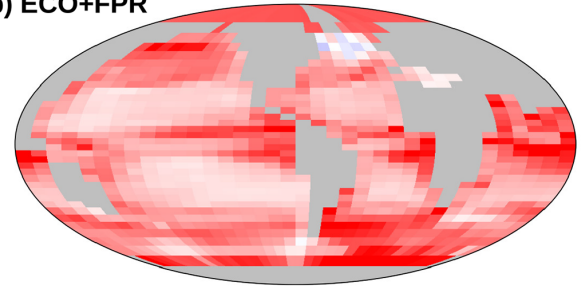

(c) ECO+TDR

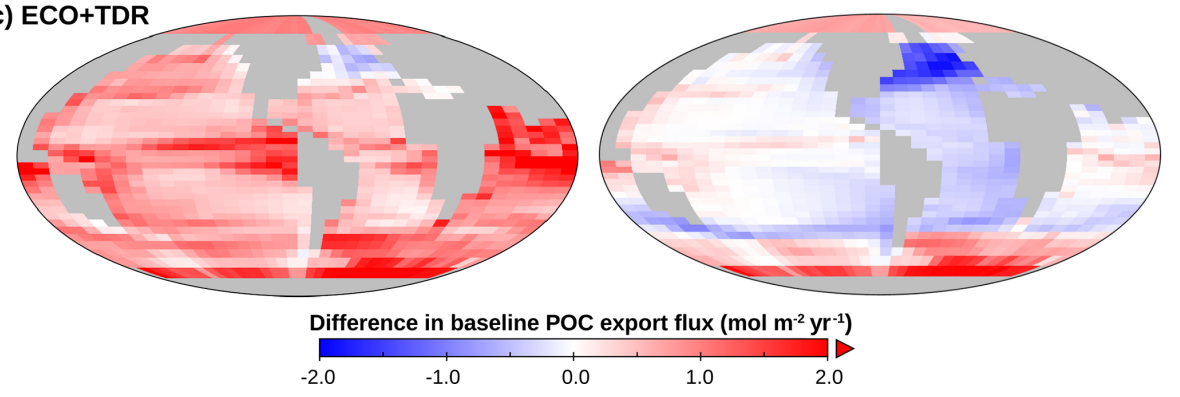

Figure 4. cGEnIE and ecoGEnIE POC export maps, showing changes in baseline for BIO+TDR (a), ECO+FPR (b), and ECO+TDR (c) in the default calibration (left) and recalibrations (right) relative to the default BIO+FPR configuration (Fig. 3a, left). Plot created with Panoply, available from NASA Goddard Space Flight Center.

phytoplankton with higher nutrient affinities, and resulted in increased particulate export from larger phytoplankton and inefficient zooplankton feeding despite lower overall ecosystem biomass (Ward et al., 2014). When baseline nutrient fluxes were instead elevated without higher temperatures, increases in small phytoplankton biomass were again limited by zooplankton grazing and allowed larger phytoplankton to be more competitive; however, unlike warming alone, higher nutrient fluxes facilitated both elevated total ecosystem production and export. In our ecoGEnIE results though, transient warming is accompanied by both stratification and reduced nutrient flux at lower latitudes, resulting in an overall shift to smaller phytoplankton dominance despite warming allowing for greater phytoplankton nutrient usage and grazing. This reduces total ecosystem biomass and, therefore, POC export at lower latitudes, which the consequent reduction in large phytoplankton abundance and grazing upon them further accentuates. In combination, this leads to a greater decline in POC export in ECO+FPR than in BIO+FPR.

In contrast to low latitudes, in most high-latitude waters biomass increases whereas mean cell size and export decline (Figs. 3c, S51, S52, and S55 in the Supplement); along the Antarctic Polar Front, biomass decreases, mean cell size is stable or increases, and POC export increases. These changes in the Antarctic Polar front are because warming in nutrientrich upwelling regions allows for increased zooplankton and larger phytoplankton abundance (Figs. S56-S61 in the Supplement), leading to restrained total biomass due to grazing coupled with increased export. In non-upwelling polar regions such as the western Arctic where nutrients are limited but - unlike at low latitudes - warming-induced stratification does not restrict nutrient flux further, warming preferentially boosts smaller phytoplankton (6 vs. $19 \mu \mathrm{m})$, which, along with a commensurate decline in dependent zooplankton $(19 \mu \mathrm{m})$ and top-down grazing pressure, leads to increased overall biomass but lower export. In the eastern Arctic this process is not as apparent due to the interference of overturning circulation slowdown resulting in a moderate reduction in formerly elevated nutrient availability. This leads to a reduction in medium relative to small phytoplankton classes (19 vs. 1.9 and $6 \mu \mathrm{m}$ ) and a commensurate shift to smaller zooplankton classes ( 6 and 19 vs. $60 \mu \mathrm{m}$ ), and, therefore, relatively stable biomass and mean cell size coupled with reduced export.

Adding both trait-based plankton ecology and TDR (ECO+TDR) produces a complex result, with the weakening effect of adding ECO on the biological pump partly counteracting the strengthening effect of adding TDR. The overall 
effect is a moderate reduction in POC flux by $\sim 2.7 \%$ by 2100 CE under RCP4.5 and $\sim 5.4 \%$ under RCP8.5 (Fig. 2), as decreasing plankton size and POC export in lower-latitude waters due to adding ECO reduces the capacity for nutrient recycling to increase as a result of adding TDR (Fig. 4c). The combined effect of ECO+TDR relative to BIO+FPR in this model is, therefore, $\sim 0.1 \%$ more cumulative POC export by $2100 \mathrm{CE}$ (Fig. 3d), resulting in $\sim 5 \mathrm{PgC}$ more POC being exported by the biological pump in this model by $2100 \mathrm{CE}$. In all configurations and scenarios, the changes in the biological pump continue past $2100 \mathrm{CE}$ and, in many cases, only begin to stabilise after several hundred years (Fig. 2).

Using recalibrated instead of the published default calibrations for each configuration results in the same overall pattern of TDR ameliorating and ECO amplifying the biological pump weakening with warming, although with a greater weakening for ECO+FPR and ECO+TDR, reduced long-term strengthening for BIO+TDR, and a greater rather than smaller net weakening in ECO+TDR relative to BIO+FPR $(-\sim 1.4 \%$ vs. $+\sim 0.1 \%$; Fig. S62 in the Supplement). These recalibrations correct for the substantially different baseline biological pumps in the default calibrations, with baseline POC export of $\sim 8.1 \mathrm{PgC} \mathrm{yr}^{-1}$ in BIO+TDR, $\sim 11.3 \mathrm{PgCyr}^{-1}$ in ECO+FPR, and $\sim$ $11 \mathrm{PgC} \mathrm{yr}^{-1}$ in ECO+TDR (Fig. 4, left). High production and export leads to differing initial ecosystem structure, leading to amplified effects on remineralisation when POC export changes with warming, which acts as a confounding factor when comparing their responses. However, in order to make baseline POC export equivalent in the ECO recalibrations, it was necessary to substantially increase the recalcitrant fraction of POC export. This leads to reduced remineralisation in intermediate waters and gradually limits surface nutrient supply; therefore, the increased recalcitrant fraction is a factor in the amplified decline in POC export observed in our ECO recalibration results. The general pattern of our results though - activating TDR or ECO leading to a relative strengthening or weakening of the biological pump respectively, and activating both leading to an overall weakening - is consistent across the different calibrations, indicating that these trends are robust.

\subsection{Ocean carbon sink capacity}

In previous discussions of empirical and model results it has been understood that a decrease in biological pump strength directly leads to a corresponding decrease in the ocean carbon sink capacity, as less POC is exported from the surface to deep ocean and so more $\mathrm{CO}_{2}$ remains in surface waters and, therefore, the atmosphere (Boscolo-Galazzo et al., 2018; John et al., 2014a; Olivarez Lyle and Lyle, 2006; Steffen et al., 2018). This is the case when comparing long-term equilibrium states, with, for example, warm palaeoclimate states with a stronger biological pump storing more carbon in the ocean. However, in transient scenarios, such as the present day, reduced POC export affects many other processes, which results in a non-linear relation between biological pump strength and the ocean carbon sink capacity that can lead to counter-intuitive outcomes (Gnanadesikan and Marinov, 2008; Kwon et al., 2009).

In our simulations, the relative strengthening of the biological pump when TDR is included actually leads to a $\sim 1.0 \%$ net decrease in the ocean carbon sink capacity by 2100 CE (Table 2, Fig. 5). Conversely, the relative weakening of the biological pump with ECOGEM activated instead (ECO+FPR) is associated with a $\sim 0.2 \%$ net increase in the ocean carbon sink capacity. Combining both ECOGEM and TDR (ECO+TDR) results in a smaller overall relative weakening of the biological pump compared with default, and $\mathrm{a} \sim 0.7 \%$ net decrease in the ocean carbon sink capacity ( $\sim 3.9 \mathrm{PgC}$ under RCP4.5, $\sim 6.2 \mathrm{PgC}$ under RCP8.5) by $2100 \mathrm{CE}$ (Table 2). The physical climate and circulation response is effectively identical across these different configurations, indicating that the differences are biogeochemically driven. Therefore, including trait-based ecology using size classes, largely but not entirely, offsets the impact on the ocean carbon sink of also including TDR in this model during the 21 st century. Hence, the model suggests that ecological dynamics increases the resilience of plankton ecosystem functioning against the pressures of climate change.

A decrease in particulate export does not automatically result in a decrease in the ocean carbon sink capacity in this model as a result of changing remineralisation depths and interactions with carbonate chemistry and ocean acidification. Adding TDR results in greater production of both POC and PIC relative to BIO+FPR in non-polar regions in response to warming shoaling the remineralisation depth, as described in the Sect. 4.2. This has two effects in our results. Firstly, shallower remineralisation and increased POC export from remineralised nutrients results in an increase in respired $\mathrm{CO}_{2}$ in surface waters relative to $\mathrm{BIO}+\mathrm{FPR}$. Secondly, increased $\mathrm{CaCO}_{3}$ formation and surface nutrient remineralisation also results in overall lower ALK in surface waters relative to BIO+FPR, which (through DIC speciation) leads to an overall decrease in the concentration of dissolved carbonate $\left(\left[\mathrm{CO}_{3}\right]\right)$ and decreased surface $\mathrm{pH}$ and carbonate saturation state $(\Omega)$ (Fig. S63 in the Supplement) (as theoretically described by Zeebe and Wolf-Gladrow, 2001, and similar to the mechanisms described by Kwon et al., 2009). Together with shallower remineralisation, this increases the partial pressure of $\mathrm{CO}_{2}$ in surface waters $\left(p \mathrm{CO}_{2}\right)$, thereby reducing the capacity for additional $\mathrm{CO}_{2}$ to dissolve from the atmosphere into the ocean. This effect on the air-to-sea $\mathrm{CO}_{2}$ flux gradually limits the total DIC content for the whole ocean and, therefore, the ocean carbon sink as a whole (see explanatory schematic in Fig. S64 in the Supplement). Ocean acidification also concurrently increases surface $p \mathrm{CO}_{2}$ and decreases $\Omega$ and PIC production (Fig. S65 in the Supplement); thus, adding TDR tends to amplify ocean acidification by further increasing surface $p \mathrm{CO}_{2}$ in response to warming. 

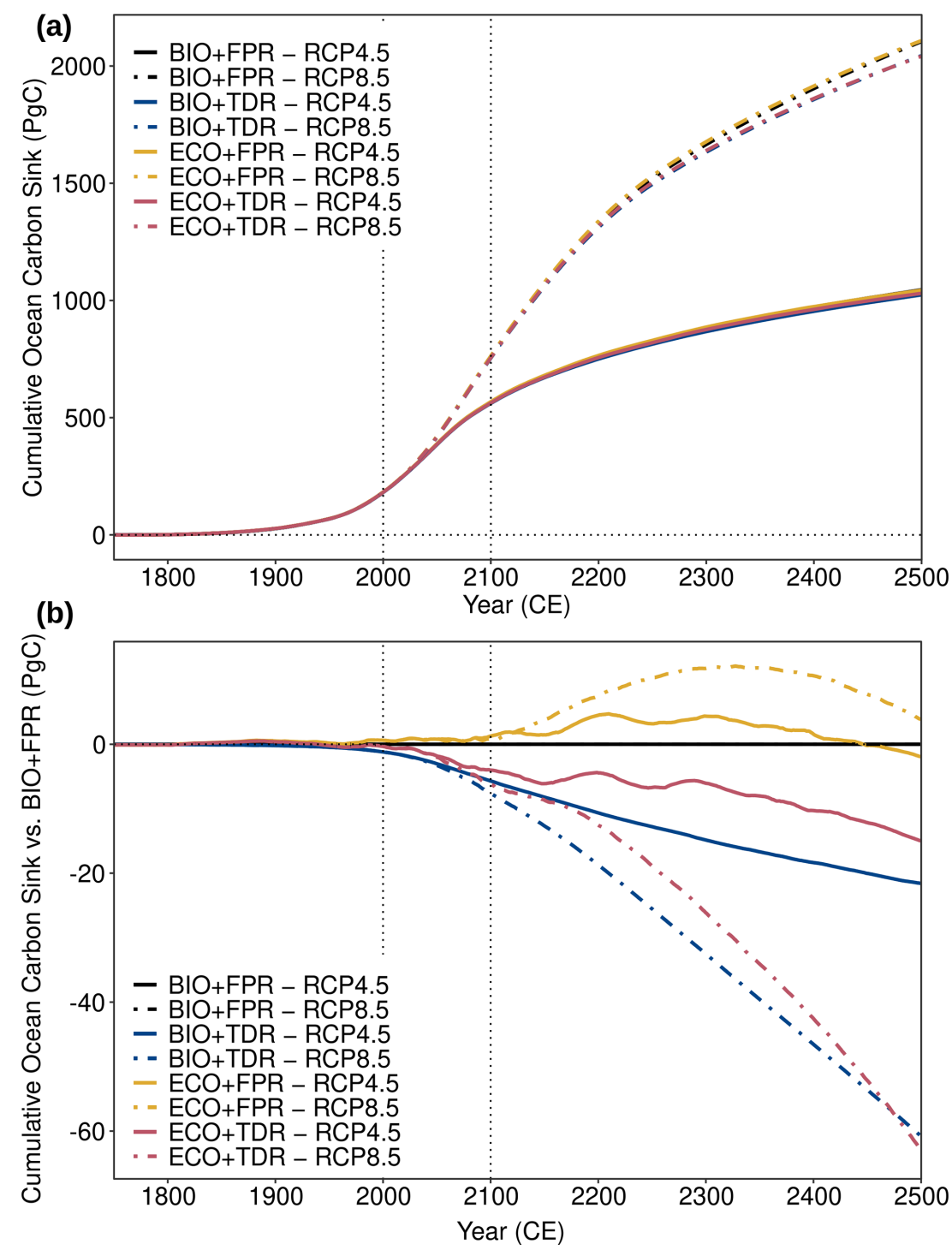

Figure 5. cGEnIE and ecoGEnIE simulation results for (a) the absolute cumulative ocean carbon sink and (b) the cumulative ocean carbon sink relative to BIO+FPR under different configurations and forcing scenarios. Results for RCP4.5 (solid lines) and RCP8.5 (dot-dashed lines) are shown for each of the default calibration configurations (BIO+FPR - black; BIO+TDR - blue; ECO+FPR - yellow; ECO+TDR red), and the 21 st century is marked by the vertical dotted lines.

Conversely, as shown in Sect. 4.2, adding ECOGEM instead reduces total ecosystem biomass and POC export with warming relative to $\mathrm{BIO}+\mathrm{FPR}$ as a result of the shift to smaller plankton taxa. This shift increases the DOM : POM production ratio, which results in a greater reduction in POC export and subsurface remineralisation. $\mathrm{CaCO}_{3}$ formation and PIC export is also reduced as $\mathrm{CaCO}_{3}$ production is fixed as a saturation-state-dependent ratio to POC export in this version of ecoGEnIE. In combination, this leads to lower DIC, higher ALK, increased $\left[\mathrm{CO}_{3}\right]$ and $\Omega$ relative to BIO+FPR (Fig. S66 in the Supplement), leading to decreased $p \mathrm{CO}_{2}$ in low- and mid-latitude surface waters and increased air-to-sea $\mathrm{CO}_{2}$ flux and total ocean DIC in the long term. Introduc- ing ECOGEM and the resultant oligotrophication-induced plankton size shift therefore slightly counters the ocean acidification trend.

The same experiments were also repeated using recalibrated configurations, as the default calibrations have different baseline biological pumps and carbonate chemistry which act as confounding factors in their response. Compared with the recalibrations' baseline, POC production and export is higher and more resilient in the default TDR and ECO calibrations (Table S1); therefore, changes in POC export have a reduced impact on surface carbonate chemistry than if the export baseline were equivalent. In the ECO configurations $\left[\mathrm{CO}_{3}\right]$ is also much lower $(\sim 70-80$ vs. 
$\sim 106 \mu \mathrm{molkg}^{-1}$ in BIO+FPR) and $\left[\mathrm{CO}_{2}\right]$ is much higher $\left(\sim 40-50\right.$ vs. $24 \mu \mathrm{mol} \mathrm{kg}{ }^{-1}$ in BIO+FPR) than in the recalibrations, resulting in substantially weaker carbonate buffering in the default configurations. Using the recalibrations instead (Fig. S67 in the Supplement) increases the long-term sink strengthening effect by ECO and reduces sink weakening by TDR relative to the default configurations, which after the 21 st century results in a net sink strengthening with ECO+TDR rather than a net weakening. However, the small differences in surface carbonate chemistry between the recalibrated configurations still have some confounding effects on our carbon sink results, as does the adjustment of POC export parameters. As discussed in Sect. 4.2, a higher recalcitrant POC fraction in the ECO recalibrations reduces remineralisation in intermediate waters and gradually reduces surface nutrient supply and productivity, which amplifies the carbon sink capacity reduction described above. Furthermore, the BIO+TDR recalibration has a $\sim 7.5 \%$ lower baseline $\left[\mathrm{CO}_{3}\right]$ than BIO+FPR (Table S1), which (as discussed in Sect. 3.3) somewhat reduces carbonate buffering and could therefore explain a proportion of the simulated carbon sink weakening through a reduced solubility pump. Both higher and lower $\left[\mathrm{CO}_{3}\right]$ in the respective default TDR and ECO calibrations are associated with reduced carbon sink capacity relative to the recalibrations though, while ECO+FPR shows an increase in carbon sink capacity in the recalibrated configurations despite lower $\left[\mathrm{CO}_{3}\right]$ than ECO+TDR. In combination, this indicates that $\left[\mathrm{CO}_{3}\right]$ has a relatively minor impact on the sign and magnitude of our carbon sink results, and although the POC recalcitrant fraction recalibration does affect our results more strongly, the broad trends of relative sink weakening with TDR and relative sink strengthening with ECO are robust.

\section{Discussion}

These results clearly illustrate the importance of incorporating multiple dimensions of ecological complexity within Earth system models in order to capture the impact of nonlinear climate-biosphere feedbacks, biodiversity, and ecological resilience on the future dynamics of carbon sinks. However, although the introduction of either TDR or ECO leads to opposing trends in POC export in response to warming, the overall impact on the ocean carbon sink is relatively modest. Our cGEnIE experiments simulate a decline in the ocean carbon sink capacity of around $\sim 6.5 \mathrm{PgC}\left(\sim 0.06 \mathrm{PgC} \mathrm{yr}^{-1}\right)$ during the 21 st century under an RCP8.5 scenario when accounting for TDR. This can be compared to a previous estimate of a $\sim 18 \mathrm{PgC}\left(\sim 0.18 \mathrm{PgC} \mathrm{yr}^{-1}\right)$ decline in ocean carbon sink capacity by $2100 \mathrm{CE}$ in response to RCP 8.5 made using a simpler NPZD-based ecosystem representation that differentiated silicifying plankton (Segschneider and Bendtsen, 2013), and to the 2018 ocean carbon sink uptake rate of $2.6 \pm 0.6 \mathrm{PgC} \mathrm{yr}^{-1}$ (Friedlingstein et al., 2019). This de- cline is partially countered when greater ecological complexity and flexible stoichiometry is introduced as well, with a shift to smaller plankton classes in response to oligotrophication leading to a 21 st century ocean carbon sink reduction of $\sim 5.9 \mathrm{PgC}$. Other processes that are not resolved in this configuration of ecoGEnIE could also substantially affect the biological pump, such as ballasting, calcifier-silicifier tradeoffs, nitrogen cycle and stoichiometry-acidification feedbacks (Buchanan et al., 2019; Dutkiewicz et al., 2015; Landolfi et al., 2017; Riebesell et al., 2007; Somes et al., 2016; Tagliabue et al., 2011), deep chlorophyll maxima, and (on longer timescales) redox-dependent feedbacks (Niemeyer et al., 2017; Watson, 2016). Limited physical resolution can have significant impacts on biogeochemistry (Sinha et al., 2010), also limiting our results. Further work is required to assess the impact of these features on our estimates.

Few of the ESMs used in CMIP5 sufficiently resolve marine ecology, instead relying on simple plankton ecosystems that are often highly parameterised with minimal or nonexistent ecological and metabolic dynamics (Table 1). This reduces computational expense, allowing higher resolution of important physical processes, but it comes at the price of poorly resolving known biogeochemical and ecological feedbacks that can substantially affect carbon partitioning (Anderson, 2005; Ward et al., 2018). To date, gains in computational power have largely been allocated to improved resolution and physical process representation, whereas despite recent progress, biogeochemical parameters have remained too poorly constrained to allow greater biogeochemical complexity in high-resolution ESMs. However, the development of trait-based ecological models could enable ESMs to include more complex marine biogeochemical modules without compromising the high-resolution representation of physical processes. An approach that focuses on functional traits and generic ecosystem rules potentially reduces the need for taxonomy-specific parameterisations and also allows for better representation of allometric effects. Development of biogeochemical models with higher physical resolution would also allow more accurate representation of fine-scale biogeochemical processes such as the interaction of stratification, the nutricline, and deep chlorophyll maxima in oligotrophic regions (Richardson and Bendtsen, 2017, 2019), which are issues raised in this study that have not been possible to explore. EMICs with lower physical resolution can more readily incorporate ecological complexity though, and they remain a crucial tool for further exploring these feedbacks in the interim (Chien et al., 2020; Frants et al., 2016; Kriest, 2017; Kriest et al., 2020; Niemeyer et al., 2019; Sauerland et al., 2019; Schartau et al., 2017; Ward et al., 2018; Wilson et al., 2018; Yao et al., 2019).

In this study, we focus on the dominant soft tissue biological pump, but the variable response of plankton classes with different shell types to climate change and ocean acidification also has an impact on the biological pump. For instance, silicifiers with opal-based shells, such as diatoms, 
thrive in nutrient-rich waters. Segschneider and Bendtsen (2013) found that the increased nutrient recycling when TDR was introduced in their model initially drives an increase in diatom production and opal export in response to climate change. In their model, this soon leads to silicate-depleted surface waters and suppressed diatom production, allowing a subsequent increase in calcifying plankton and PIC export instead. This has the effect of reducing surface alkalinity and increasing surface $p \mathrm{CO}_{2}$, which drives a substantial proportion of the large ocean carbon sink reduction in their analysis. Despite the likely importance of this "hard-shell" mechanism, ecoGEnIE does not currently allow independent representation of calcifiers and does not represent silicifiers at all; thus, the potential impact of this mechanism is not resolved by our results. However, the model of Segschneider and Bendtsen (2013) does not feature size classes or flexible stoichiometry, which we have shown is important for determining the soft tissue biological pump response, and their results did not account for the effects of ocean acidification. In order to fully compare our results it will be necessary to repeat these simulations with the silicifier-enabled ECOGEM currently under development. Together, resolving plankton size classes, TDR, flexible stoichiometry, and separate silicifier and calcifier functional types will allow the response of the marine biological pump to climate change to be more fully diagnosed.

Further development will also allow the potential impact of ballasting to be assessed. Using a different EMIC, Kvale et al. $(2015,2019)$ found that adding ballasting alongside calcifier functional types mitigated the biological pump response to ocean warming by facilitating increased calcifier production and, therefore, increasing nutrient export from the surface. In contrast, activating ballasting in ecoGEnIE without separating out a competitive calcifier functional type would likely result in greater surface water remineralisation in scenarios with reduced PIC production. However, empirical observations have suggested that the ballasting effect on the ocean carbon sink is weaker than has been hypothesised (Wilson et al., 2012).

\section{Conclusions}

The response of the biological pump to climate change is important for projecting climate feedbacks and the future behaviour of the ocean carbon sink, but many of the most influential Earth system models fail to incorporate sufficient metabolic or ecological complexity for this to be fully resolved. In this study, we have investigated the impact of integrating temperature-dependent remineralisation, size-based biodiversity, and flexible nutrient usage on the biological pump and ocean carbon sink in response to climate change. As expected, we found that adding temperature-dependent remineralisation to an Earth system model of intermediate complexity (ecoGEnIE) results in a greater weakening of the ocean carbon sink as a result of climate change. However, this actually results from a relative strengthening of the biological pump itself as a result of shallower nutrient remineralisation, contrary to the common expectation that the direct effect of warming further amplifies a weakening of the biological pump. Conversely, adding trait-based ecosystem dynamics instead results in an even weaker biological pump, as a result of oligotrophication favouring smaller plankton, and in turn a larger ocean carbon sink. Finally, combining both of these features results in a small relative strengthening of the biological pump and a modest reduction in the ocean carbon sink capacity relative to default simulations.

Together, this implies that the biological pump positive feedback on climate change may be larger than CMIP5 ESMs project but is potentially less than some more recent model projections (Segschneider and Bendtsen, 2013; Steffen et al., 2018). This study has primarily focused on the allometric aspects of dominant soft tissue components of the biological pump, and the results clearly illustrate the substantial degree to which ecological dynamics and biodiversity can modulate the strength of climate-biosphere feedbacks. These complex relations require further analyses and validation, but comparison of model studies is presently a challenge because today's ESMs take such different approaches and simplifications. In future, trait-based ecological modules that go beyond simple biogeochemical traits could enable ESMs to include more ecological complexity without compromising the high-resolution representation of physical processes, allowing feedbacks such as the marine biological pump to be more fully resolved.

Data availability. The version of cGENIE.muffin used in this paper is tagged as release v0.9.13 and has been assigned the following DOI: https://doi.org/10.5281/zenodo.3999080 (Ridgwell et al., 2020a). The latex source of the manual corresponding to the model version in this paper, along with a pre-built PDF file, is tagged as release v0.9.13 and has been assigned the following DOI: https: //doi.org/10.5281/zenodo.4305997 (Ridgwell et al., 2020b). Modern observational data regridded onto the cGEnIE model grid (Ward et al., 2018) for model-data comparison are available from https: //www.seao2.info/mymuffin.html (Ridgwell, 2021). $\mathrm{CO}_{2}$ emission scenarios for forcing the model are available from http://www. pik-potsdam.de/ mmalte/rcps/ (Meinshausen et al., 2011).

Supplement. The supplement related to this article is available online at: https://doi.org/10.5194/esd-12-797-2021-supplement.

Author contributions. DIAM, SEC, and KR conceived of the study; DIAM designed the study, configured and ran the model, and performed the analyses; DIAM wrote the paper with input from SEC, KR, and JR. 
Competing interests. The authors declare that they have no conflict of interest.

Disclaimer. Publisher's note: Copernicus Publications remains neutral with regard to jurisdictional claims in published maps and institutional affiliations.

Acknowledgements. We thank Andy Ridgwell and Ben Ward for discussions on using ecoGEnIE, and Toby Tyrrell for discussions on variable stoichiometry.

Financial support. This research has been supported by the European Research Council (Earth Resilience in the Anthropocene project, grant no. ERA 743080).

The article processing charges for this open-access publication were covered by Stockholm University.

Review statement. This paper was edited by Michel Crucifix and reviewed by Jamie Wilson and one anonymous referee.

\section{References}

Anderson, T. R.: Plankton functional type modelling: Running before we can walk?, J. Plankton Res., 27, 1073-1081, https://doi.org/10.1093/plankt/fbi076, 2005.

Armstrong, R. A., Lee, C., Hedges, J. I., Honjo, S., and Wakeham, S. G.: A new, mechanistic model for organic carbon fluxes in the ocean based on the quantitative association of POC with ballast minerals, Deep-Sea Res. Pt. II, 49, 219-236, https://doi.org/10.1016/S0967-0645(01)00101-1, 2001.

Arora, V. K., Boer, G. J., Christian, J. R., Curry, C. L., Denman, K. L., Zahariev, K., Flato, G. M., Scinocca, J. F., Merryfield, W. J., and Lee, W. G.: The Effect of Terrestrial Photosynthesis Down Regulation on the Twentieth-Century Carbon Budget Simulated with the CCCma Earth System Model, J. Clim., 22, 6066-6088, https://doi.org/10.1175/2009JCLI3037.1, 2009.

Arora, V. K., Scinocca, J. F., Boer, G. J., Christian, J. R., Denman, K. L., Flato, G. M., Kharin, V. V, Lee, W. G., and Merryfield, W. J.: Carbon emission limits required to satisfy future representative concentration pathways of greenhouse gases, Geophys. Res. Lett., 38, https://doi.org/10.1029/2010GL046270, 2011.

Arora, V. K., Boer, G. J., Friedlingstein, P., Eby, M., Jones, C. D., Christian, J. R., Bonan, G., Bopp, L., Brovkin, V., Cadule, P., Hajima, T., Ilyina, T., Lindsay, K., Tjiputra, J. F., and $\mathrm{Wu}, \mathrm{T}$.: Carbon-concentration and carbon-climate feedbacks in CMIP5 earth system models, J. Climate, 26(15), 5289-5314, https://doi.org/10.1175/JCLI-D-12-00494.1, 2013.

Aumont, O., Maier-Reimer, E., Blain, S., and Monfray, P.: An ecosystem model of the global ocean including $\mathrm{Fe}$, Si, P colimitations, Global Biogeochem. Cy., 17, 1-15, https://doi.org/10.1029/2001GB001745, 2003.
Aumont, O. and Bopp, L.: Globalizing results from ocean in situ iron fertilization studies, Global Biogeochem. Cycles, 20, 1-15, https://doi.org/10.1029/2005GB002591, 2006.

Beaugrand, G., Edwards, M., and Legendre, L.: Marine biodiversity, ecosystem functioning, and carbon cycles, Proc. Natl. Acad. Sci. USA, 107, 10120-10124, https://doi.org/10.1073/pnas.0913855107, 2010.

Bendtsen, J., Hilligsøe, K. M., Hansen, J. L. S., and Richardson, K.: Analysis of remineralisation, lability, temperature sensitivity and structural composition of organic matter from the upper ocean, Prog. Oceanogr., 130, 125-145, https://doi.org/10.1016/j.pocean.2014.10.009, 2015.

Bopp, L., Aumont, O., Cadule, P., Alvain, S., and Gehlen, M.: Response of diatoms distribution to global warming and potential implications: A global model study, Geophys. Res. Lett., 32, 14, https://doi.org/10.1029/2005GL023653, 2005.

Bopp, L., Resplandy, L., Orr, J. C., Doney, S. C., Dunne, J. P., Gehlen, M., Halloran, P., Heinze, C., Ilyina, T., Séférian, R., Tjiputra, J., and Vichi, M.: Multiple stressors of ocean ecosystems in the 21st century: projections with CMIP5 models, Biogeosciences, 10, 6225-6245, https://doi.org/10.5194/bg-106225-2013, 2013.

Boscolo-Galazzo, F., Crichton, K. A., Barker, S., and Pearson, P. N.: Temperature dependency of metabolic rates in the upper ocean: A positive feedback to global climate change?, Global Planet. Change, 170, 201-212, https://doi.org/10.1016/j.gloplacha.2018.08.017, 2018.

Broecker, W. S. and Peng, T.-H.: Tracers in the sea, LamontDoherty Geological Observatory, Palisades, New York, 1982.

Bruggeman, J. and Kooijman, S. A. L. M.: A biodiversity-inspired approach to aquatic ecosystem modeling, Limnol. Oceanogr., 52, 1533-1544, https://doi.org/10.4319/lo.2007.52.4.1533, 2007.

Buchanan, P. J., Chase, Z., Matear, R. J., Phipps, S. J., and Bindoff, N. L.: Marine nitrogen fixers mediate a low latitude pathway for atmospheric $\mathrm{CO}_{2}$ drawdown, Nat. Commun., 10, 1-10, https://doi.org/10.1038/s41467-019-12549-z, 2019.

Cabré, A., Marinov, I., and Leung, S.: Consistent global responses of marine ecosystems to future climate change across the IPCC AR5 earth system models, Clim. Dynam., 45, 1253-1280, https://doi.org/10.1007/s00382-014-2374-3, 2015.

Chien, C.-T., Pahlow, M., Schartau, M., and Oschlies, A.: Optimality-based non-Redfield plankton-ecosystem model (OPEM v1.1) in UVic-ESCM 2.9 - Part 2: Sensitivity analysis and model calibration, Geosci. Model Dev., 13, 4691-4712, https://doi.org/10.5194/gmd-13-4691-2020, 2020.

Christian, J. R., Arora, V. K., Boer, G. J., Curry, C. L., Zahariev, K., Denman, K. L., Flato, G. M., Lee, W. G., Merryfield, W. J., Roulet, N. T., and Scinocca, J. F.: The global carbon cycle in the Canadian Earth system model (CanESM1): Preindustrial control simulation, J. Geophys. Res., 115, G03014, https://doi.org/10.1029/2008JG000920, 2010.

Ciais, P., Sabine, C., Bala, G., Bopp, L., Brovkin, V., Canadell, J., Chhabra, A., DeFries, R., Galloway, J., Heimann, M., Jones, C., Quéré, C. Le, Myneni, R. B., Piao, S., and Thornton, P.: Carbon and Other Biogeochemical Cycles, in Climate Change 2013 The Physical Science Basis, edited by: Intergovernmental Panel on Climate Change, 465-570, Cambridge University Press, Cambridge, 2013. 
Claussen, M., Mysak, L., Weaver, A., Crucifix, M., Fichefet, T., Loutre, M. F., Weber, S., Alcamo, J., Alexeev, V., Berger, A., Calov, R., Ganopolski, A., Goosse, H., Lohmann, G., Lunkeit, F., Mokhov, I., Petoukhov, V., Stone, P., and Wang, Z.: Earth system models of intermediate complexity: Closing the gap in the spectrum of climate system models, Clim. Dynam., 18, 579-586, https://doi.org/10.1007/s00382-001-0200-1, 2002.

Collins, W. J., Bellouin, N., Doutriaux-Boucher, M., Gedney, N., Halloran, P., Hinton, T., Hughes, J., Jones, C. D., Joshi, M., Liddicoat, S., Martin, G., O'Connor, F., Rae, J., Senior, C., Sitch, S., Totterdell, I., Wiltshire, A., and Woodward, S.: Development and evaluation of an Earth-System model - HadGEM2, Geosci. Model Dev., 4, 1051-1075, https://doi.org/10.5194/gmd-4-10512011, 2011.

Collins, M., Knutti, R., Arblaster, J., Dufresne, J.-L., Fichefet, T., Friedlingstein, P., Gao, X., Gutowski, W. J., Johns, T., Krinner, G., Shongwe, M., Tebaldi, C., Weaver, A. J., and Wehner, M.: Long-term Climate Change: Projections, Commitments and Irreversibility, in Climate Change 2013: The Physical Science Basis. Contribution of Working Group I to the Fifth Assessment Report of the Intergovernmental Panel on Climate Change, edited by: Stocker, T. F., Qin, D., Plattner, G.-K., Tignor, M., Allen, S. K., Boschung, J., Nauels, A., Xia, Y., Bex, V., and Midgley, P. M., 1029-1136, Cambridge University Press, Cambridge, UK, New York, USA, 2013.

Crichton, K. A., Wilson, J. D., Ridgwell, A., and Pearson, P. N.: Calibration of temperature-dependent ocean microbial processes in the cGENIE.muffin (v0.9.13) Earth system model, Geosci. Model Dev., 14, 125-149, https://doi.org/10.5194/gmd-14-1252021, 2021.

Doney, S. C., Busch, D. S., Cooley, S. R., and Kroeker, K. J.: The Impacts of Ocean Acidification on Marine Ecosystems and Reliant Human Communities, Annu. Rev. Env. Resour., 45, 1-30, https://doi.org/10.1146/annurev-environ-012320-083019, 2020.

Dugdale, R. C. and Goering, J. J.: Uptake of New and Regenerated Forms of Nitrogen in Primary Productivity, Limnol. Oceanogr., 12, 196-206, https://doi.org/10.4319/lo.1967.12.2.0196, 1967.

Dunne, J. P., Sarmiento, J. L., and Gnanadesikan, A.: A synthesis of global particle export from the surface ocean and cycling through the ocean interior and on the seafloor, Global Biogeochem. Cy., 21, 1-16, https://doi.org/10.1029/2006GB002907, 2007.

Dunne, J. P., John, J. G., Adcroft, A. J., Griffies, S. M., Hallberg, R. W., Shevliakova, E., Stouffer, R. J., Cooke, W., Dunne, K. A., Harrison, M. J., Krasting, J. P., Malyshev, S. L., Milly, P. C. D., Phillipps, P. J., Sentman, L. T., Samuels, B. L., Spelman, M. J., Winton, M., Wittenberg, A. T., and Zadeh, N.: GFDL's ESM2 Global Coupled Climate-Carbon Earth System Models. Part I: Physical Formulation and Baseline Simulation Characteristics, J. Clim., 25, 6646-6665, https://doi.org/10.1175/JCLI-D11-00560.1, 2012.

Dunne, J. P., John, J. G., Shevliakova, E., Stouffer, R. J., Krasting, J. P., Malyshev, S. L., Milly, P. C. D., Sentman, L. T., Adcroft, A. J., Cooke, W., Dunne, K. A., Griffies, S. M., Hallberg, R. W., Harrison, M. J., Levy, H., Wittenberg, A. T., Phillips, P. J. and Zadeh, N.: GFDL's ESM2 Global Coupled Climate-Carbon Earth System Models. Part II: Carbon System Formulation and Baseline Simulation Characteristics, J. Clim., 26, 2247-2267, https://doi.org/10.1175/JCLI-D-12-00150.1, 2013.
Dutkiewicz, S., Morris, J. J., Follows, M. J., Scott, J., Levitan, O., Dyhrman, S. T., and Berman-Frank, I.: Impact of ocean acidification on the structure of future phytoplankton communities, Nat. Clim. Change, 5, 1002-1006, https://doi.org/10.1038/nclimate2722, 2015.

Edwards, N. R. and Marsh, R.: Uncertainties due to transportparameter sensitivity in an efficient 3-D ocean-climate model, Clim. Dynam., 24, 415-433, https://doi.org/10.1007/s00382004-0508-8, 2005.

Eppley, R. W.: Temperature and phytoplankton growth in the sea, Fish. Bull., 70, 1063-1085, 1972.

Fakhraee, M., Planavsky, N. J., and Reinhard, C. T.: The role of environmental factors in the long-term evolution of the marine biological pump, Nat. Geosci., 13, 812-816, https://doi.org/10.1038/s41561-020-00660-6, 2020.

Finkel, Z. V., Beardall, J., Flynn, K. J., Quigg, A., Rees, T. A. V., and Raven, J. A.: Phytoplankton in a changing world: cell size and elemental stoichiometry, J. Plankton Res., 32, 119-137, https://doi.org/10.1093/plankt/fbp098, 2010.

Flato, G., Marotzke, J., Abiodun, B., Braconnot, P., Chou, S. C., Collins, W., Cox, P., Driouech, F., Emori, S., Eyring, V., Forest, C., Gleckler, P., Guilyardi, E., Jakob, C., Kattsov, V., Reason, C., and Rummukainen, M.: Evaluation of Climate Models, in Climate Change 2013 - The Physical Science Basis. Contribution of Working Group I to the Fifth Assessment Report of the Intergovernmental Panel on Climate Change, edited by: Stocker, T. F., Qin, D., Plattner, G.-K., Tignor, M., Allen, S. K., Boschung, J., Nauels, A., Xia, Y., Bex, V., and Midgley, P. M., Cambridge University Press, Cambridge, 2013.

Follows, M. J., Dutkiewicz, S., Grant, S., and Chisholm, S. W.: Emergent biogeography of microbial communities in a model ocean, Science, 315, 1843-1846, https://doi.org/10.1126/science.1138544, 2007.

Frants, M., Holzer, M., DeVries, T., and Matear, R.: Constraints on the global marine iron cycle from a simple inverse model, J. Geophys. Res.-Biogeo., 121, 28-51, https://doi.org/10.1002/2015JG003111, 2016.

Friedlingstein, P., Jones, M. W., O'Sullivan, M., Andrew, R. M., Hauck, J., Peters, G. P., Peters, W., Pongratz, J., Sitch, S., Le Quéré, C., Bakker, D. C. E., Canadell, J. G., Ciais, P., Jackson, R. B., Anthoni, P., Barbero, L., Bastos, A., Bastrikov, V., Becker, M., Bopp, L., Buitenhuis, E., Chandra, N., Chevallier, F., Chini, L. P., Currie, K. I., Feely, R. A., Gehlen, M., Gilfillan, D., Gkritzalis, T., Goll, D. S., Gruber, N., Gutekunst, S., Harris, I., Haverd, V., Houghton, R. A., Hurtt, G., Ilyina, T., Jain, A. K., Joetzjer, E., Kaplan, J. O., Kato, E., Klein Goldewijk, K., Korsbakken, J. I., Landschützer, P., Lauvset, S. K., Lefèvre, N., Lenton, A., Lienert, S., Lombardozzi, D., Marland, G., McGuire, P. C., Melton, J. R., Metzl, N., Munro, D. R., Nabel, J. E. M. S., Nakaoka, S.-I., Neill, C., Omar, A. M., Ono, T., Peregon, A., Pierrot, D., Poulter, B., Rehder, G., Resplandy, L., Robertson, E., Rödenbeck, C., Séférian, R., Schwinger, J., Smith, N., Tans, P. P., Tian, H., Tilbrook, B., Tubiello, F. N., van der Werf, G. R., Wiltshire, A. J., and Zaehle, S.: Global Carbon Budget 2019, Earth Syst. Sci. Data, 11, 1783-1838, https://doi.org/10.5194/essd-111783-2019, 2019.

Friedrichs, M. A. M., Dusenberry, J. A., Anderson, L. A., Armstrong, R. A., Chai, F., Christian, J. R., Doney, S. C., Dunne, J., Fujii, M., Hood, R., McGillicuddy, D. J., Moore, J. K., Schar- 
tau, M., Spitz, Y. H., and Wiggert, J. D.: Assessment of skill and portability in regional marine biogeochemical models: Role of multiple planktonic groups, J. Geophys. Res.-Oceans, 112, 1-22, https://doi.org/10.1029/2006JC003852, 2007.

$\mathrm{Fu}$, W., Randerson, J. T., and Moore, J. K.: Climate change impacts on net primary production (NPP) and export production (EP) regulated by increasing stratification and phytoplankton community structure in the CMIP5 models, Biogeosciences, 13, 5151-5170, https://doi.org/10.5194/bg-13-5151-2016, 2016.

Galbraith, E. D. and Martiny, A. C.: A simple nutrientdependence mechanism for predicting the stoichiometry of marine ecosystems, Proc. Natl. Acad. Sci. USA, 112, 8199-8204, https://doi.org/10.1073/pnas.1423917112, 2015.

Galbraith, E. D., Dunne, J. P., Gnanadesikan, A., Slater, R. D., Sarmiento, J. L., Dufour, C. O., de Souza, G. F., Bianchi, D., Claret, M., Rodgers, K. B., and Marvasti, S. S.: Complex functionality with minimal computation: Promise and pitfalls of reduced-tracer ocean biogeochemistry models, J. Adv. Model. Earth Sy., 7, 2012-2028, https://doi.org/10.1002/2015MS000463, 2015.

Gibbs, S. J., Bown, P. R., Ridgwell, A., Young, J. R., Poulton, A. J., and O'Dea, S. A.: Ocean warming, not acidification, controlled coccolithophore response during past greenhouse climate change, Geology, 44, 59-62, https://doi.org/10.1130/G37273.1, 2016.

Gnanadesikan, A. and Marinov, I.: Export is not enough: Nutrient cycling and carbon sequestration, Mar. Ecol. Prog. Ser., 364, 289-294, https://doi.org/10.3354/meps07550, 2008.

Goodwin, P., Follows, M. J., and Williams, R. G.: Analytical relationships between atmospheric carbon dioxide, carbon emissions, and ocean processes, Global Biogeochem. Cy., 22, 1-12, https://doi.org/10.1029/2008GB003184, 2008.

Gruber, N., Clement, D., Carter, B. R., Feely, R. A., van Heuven, S., Hoppema, M., Ishii, M., Key, R. M., Kozyr, A., Lauvset, S. K., Lo Monaco, C., Mathis, J. T., Murata, A., Olsen, A., Perez, F. F., Sabine, C. L., Tanhua, T., and Wanninkhof, R.: The oceanic sink for anthropogenic $\mathrm{CO}_{2}$ from 1994 to 2007, Science, 363, 1193-1199, https://doi.org/10.1126/science.aau5153, 2019.

Guidi, L., Stemmann, L., Jackson, G. A., Ibanez, F., Claustre, H., Legendre, L., Picheral, M., and Gorsky, G.: Effects of phytoplankton community on production, size and export of large aggregates: A world-ocean analysis, Limnol. Oceanogr., 54, 19511963, https://doi.org/10.4319/lo.2009.54.6.1951, 2009.

Halloran, P. R.: Does atmospheric $\mathrm{CO}_{2}$ seasonality play an important role in governing the air-sea flux of $\mathrm{CO}_{2}$ ?, Biogeosciences, 9, 2311-2323, https://doi.org/10.5194/bg-9-2311-2012, 2012.

Harfoot, M. B. J., Newbold, T., Tittensor, D. P., Emmott, S., Hutton, J., Lyutsarev, V., Smith, M. J., Scharlemann, J. P. W., and Purves, D. W.: Emergent Global Patterns of Ecosystem Structure and Function from a Mechanistic General Ecosystem Model, edited by: Loreau, M., PLoS Biol., 12, e1001841, https://doi.org/10.1371/journal.pbio.1001841, 2014.

Henson, S. A., Dunne, J. P., and Sarmiento, J. L.: Decadal variability in North Atlantic phytoplankton blooms, J. Geophys. Res., 114, C04013, https://doi.org/10.1029/2008JC005139, 2009.

Henson, S. A., Sanders, R., Madsen, E., Morris, P. J., Le Moigne, F., and Quartly, G. D.: A reduced estimate of the strength of the ocean's biological carbon pump, Geophys. Res. Lett., 38, 10-14, https://doi.org/10.1029/2011GL046735, 2011.
Henson, S. A., Sanders, R., and Madsen, E.: Global patterns in efficiency of particulate organic carbon export and transfer to the deep ocean, Global Biogeochem. Cy., 26, 1-14, https://doi.org/10.1029/2011GB004099, 2012.

Hoppe, H. G., Gocke, K., Koppe, R., and Begler, C.: Bacterial growth and primary production along a north-south transect of the Atlantic Ocean, Nature, 416, 168-171, https://doi.org/10.1038/416168a, 2002.

Ilyina, T., Six, K. D., Segschneider, J., Maier-Reimer, E., Li, H., and Núñez-Riboni, I.: Global ocean biogeochemistry model HAMOCC: Model architecture and performance as component of the MPI-Earth system model in different CMIP5 experimental realizations, J. Adv. Model. Earth Syst., 5, 287-315, https://doi.org/10.1029/2012MS000178, 2013.

John, E. H., Wilson, J. D., Pearson, P. N., and Ridgwell, A.: Temperature-dependent remineralization and carbon cycling in the warm Eocene oceans, Palaeogeogr. Palaeocl., 413, 158-166, https://doi.org/10.1016/j.palaeo.2014.05.019, 2014.

Jones, C. D., Hughes, J. K., Bellouin, N., Hardiman, S. C., Jones, G. S., Knight, J., Liddicoat, S., O'Connor, F. M., Andres, R. J., Bell, C., Boo, K.-O., Bozzo, A., Butchart, N., Cadule, P., Corbin, K. D., Doutriaux-Boucher, M., Friedlingstein, P., Gornall, J., Gray, L., Halloran, P. R., Hurtt, G., Ingram, W. J., Lamarque, J.-F., Law, R. M., Meinshausen, M., Osprey, S., Palin, E. J., Parsons Chini, L., Raddatz, T., Sanderson, M. G., Sellar, A. A., Schurer, A., Valdes, P., Wood, N., Woodward, S., Yoshioka, M., and Zerroukat, M.: The HadGEM2-ES implementation of CMIP5 centennial simulations, Geosci. Model Dev., 4, 543-570, https://doi.org/10.5194/gmd-4-543-2011, 2011.

Kawamiya, M., Kishi, M. J., and Suginohara, N.: An ecosystem model for the North Pacific embedded in a general circulation model, J. Mar. Syst., 25, 129-157, https://doi.org/10.1016/S0924-7963(00)00012-9, 2000.

Keeling, R. F., Körtzinger, A., and Gruber, N.: Ocean Deoxygenation in a Warming World, Annu. Rev. Mar. Sci., 2, 199-229, https://doi.org/10.1146/annurev.marine.010908.163855, 2010.

Klaas, C. and Archer, D. E.: Association of sinking organic matter with various types of mineral ballast in the deep sea: Implications for the rain ratio, Global Biogeochem. Cy., 16, 63-1-63-14, https://doi.org/10.1029/2001gb001765, 2002.

Kraus, E. B. and Turner, J. S.: A one-dimensional model of the seasonal thermocline II. The general theory and its consequences, Tellus, 19, 98-106, https://doi.org/10.3402/tellusa.v19i1.9753, 1967.

Kriest, I.: Calibration of a simple and a complex model of global marine biogeochemistry, Biogeosciences, 14, 4965-4984, https://doi.org/10.5194/bg-14-4965-2017, 2017.

Kriest, I., Kähler, P., Koeve, W., Kvale, K., Sauerland, V., and Oschlies, A.: One size fits all? Calibrating an ocean biogeochemistry model for different circulations, Biogeosciences, 17, 30573082, https://doi.org/10.5194/bg-17-3057-2020, 2020.

Kvale, K. F., Meissner, K. J., and Keller, D. P.: Potential increasing dominance of heterotrophy in the global ocean, Environ. Res. Lett., 10, 074009, https://doi.org/10.1088/17489326/10/7/074009, 2015.

Kvale, K. F., Turner, K. E., Landolfi, A., and Meissner, K. J.: Phytoplankton calcifiers control nitrate cycling and the pace of transition in warming icehouse and cooling greenhouse climates, 
Biogeosciences, 16, 1019-1034, https://doi.org/10.5194/bg-161019-2019, 2019.

Kwiatkowski, L., Yool, A., Allen, J. I., Anderson, T. R., Barciela, R., Buitenhuis, E. T., Butenschön, M., Enright, C., Halloran, P. R., Le Quéré, C., de Mora, L., Racault, M.-F., Sinha, B., Totterdell, I. J., and Cox, P. M.: iMarNet: an ocean biogeochemistry model intercomparison project within a common physical ocean modelling framework, Biogeosciences, 11, 7291-7304, https://doi.org/10.5194/bg-11-7291-2014, 2014.

Kwiatkowski, L., Aumont, O., Bopp, L., and Ciais, P.: The Impact of Variable Phytoplankton Stoichiometry on Projections of Primary Production, Food Quality, and Carbon Uptake in the Global Ocean, Global Biogeochem. Cy., 32, 516-528, https://doi.org/10.1002/2017GB005799, 2018.

Kwon, E. Y., Primeau, F., and Sarmiento, J. L.: The impact of remineralization depth on the air-sea carbon balance, Nat. Geosci., 2, 630-635, https://doi.org/10.1038/ngeo612, 2009.

Landolfi, A., Somes, C. J., Koeve, W., Zamora, L. M., and Oschlies, A.: Oceanic nitrogen cycling and $\mathrm{N}_{2} \mathrm{O}$ flux perturbations in the Anthropocene, Global Biogeochem. Cy., 31, 1236-1255, https://doi.org/10.1002/2017GB005633, 2017.

Laws, E. A.: Photosynthetic quotients, new production and net community production in the open ocean, Deep-Sea Res., 38, 143167, https://doi.org/10.1016/0198-0149(91)90059-O, 1991.

Laws, E. A., Falkowski, P. G., Smith, W. O., Ducklow, H., and McCarthy, J. J.: Temperature effects on export production in the open ocean, Global Biogeochem. Cy., 14, 1231-1246, https://doi.org/10.1029/1999GB001229, 2000.

Leung, S. W., Weber, T., Cram, J. A., and Deutsch, C.: Variable particle size distributions reduce the sensitivity of global export flux to climate change, Biogeosciences, 18, 229-250, https://doi.org/10.5194/bg-18-229-2021, 2021.

Long, M. C., Lindsay, K., Peacock, S., Moore, J. K., and Doney, S. C.: Twentieth-Century Oceanic Carbon Uptake and Storage in CESM1(BGC), J. Clim., 26, 6775-6800, https://doi.org/10.1175/JCLI-D-12-00184.1, 2013.

Marsh, R., Müller, S. A., Yool, A., and Edwards, N. R.: Incorporation of the C-GOLDSTEIN efficient climate model into the GENIE framework: "eb_go_gs" configurations of GENIE, Geosci. Model Dev., 4, 957-992, https://doi.org/10.5194/gmd-4957-2011, 2011.

Martin, J. H., Knauer, G. A., Karl, D. M., and Broenkow, W. W.: VERTEX: carbon cycling in the northeast Pacific, Deep Sea Res., Deep-Sea Res., 34, 267-285, https://doi.org/10.1016/01980149(87)90086-0, 1987.

Martiny, A. C., Vrugt, J. A., and Lomas, M. W.: Concentrations and ratios of particulate organic carbon, nitrogen, and phosphorus in the global ocean, Scientific Data, 1, 1-7, https://doi.org/10.1038/sdata.2014.48, 2014.

Martiny, A. C., Ma, L., Mouginot, C., Chandler, J. W., and Zinser, E. R.: Interactions between thermal acclimation, growth rate, and phylogeny influence prochlorococcus elemental stoichiometry, PLoS One, 11, 1-12, https://doi.org/10.1371/journal.pone.0168291, 2016.

McGill, B. J., Enquist, B. J., Weiher, E., and Westoby, M.: Rebuilding community ecology from functional traits, Trends Ecol. Evol., 21, 178-185, https://doi.org/10.1016/j.tree.2006.02.002, 2006.
Meinshausen, M., Smith, S. J., Calvin, K., Daniel, J. S., Kainuma, M. L. T., Lamarque, J.-F., Matsumoto, K., Montzka, S. A., Raper, S. C. B., Riahi, K., Thomson, A., Velders, G. J. M., and van Vuuren, D. P. P.: The RCP greenhouse gas concentrations and their extensions from 1765 to 2300, Clim. Change, 109, 213-241, https://doi.org/10.1007/s10584-011-0156-z, 2011 (data available at: http://www.pik-potsdam.de/ mmalte/rcps/, last access: 12 July 2021).

Meyer, K. M., Ridgwell, A., and Payne, J. L.: The influence of the biological pump on ocean chemistry: Implications for longterm trends in marine redox chemistry, the global carbon cycle, and marine animal ecosystems, Geobiology, 14, 207-219, https://doi.org/10.1111/gbi.12176, 2016.

Monteiro, F. M., Pancost, R. D., Ridgwell, A., and Donnadieu, Y.: Nutrients as the dominant control on the spread of anoxia and euxinia across the Cenomanian-Turonian oceanic anoxic event (OAE2): Model-data comparison, Paleoceanography, 27, 1-17, https://doi.org/10.1029/2012PA002351, 2012.

Moore, J. K., Lindsay, K., Doney, S. C., Long, M. C., and Misumi, K.: Marine Ecosystem Dynamics and Biogeochemical Cycling in the Community Earth System Model [CESM1(BGC)]: Comparison of the 1990s with the 2090s under the RCP4.5 and RCP8.5 Scenarios, J. Clim., 26, 9291-9312, https://doi.org/10.1175/JCLI-D-12-00566.1, 2013.

Moreno, A. R. and Martiny, A. C.: Ecological Stoichiometry of Ocean Plankton, Annu. Rev. Mar. Sci., 10, 43-69, https://doi.org/10.1146/annurev-marine-121916-063126, 2018.

Moreno, A. R., Hagstrom, G. I., Primeau, F. W., Levin, S. A., and Martiny, A. C.: Marine phytoplankton stoichiometry mediates nonlinear interactions between nutrient supply, temperature, and atmospheric $\mathrm{CO}_{2}$, Biogeosciences, 15, 2761-2779, https://doi.org/10.5194/bg-15-2761-2018, 2018.

Mousing, E. A., Ellegaard, M., and Richardson, K.: Global patterns in phytoplankton community size structure -evidence for a direct temperature effect, Mar. Ecol. Prog. Ser., 497, 25-38, https://doi.org/10.3354/meps10583, 2014.

Mouw, C. B., Barnett, A., McKinley, G. A., Gloege, L., and Pilcher, D.: Global ocean particulate organic carbon flux merged with satellite parameters, Earth Syst. Sci. Data, 8, 531-541, https://doi.org/10.5194/essd-8-531-2016, 2016a.

Mouw, C. B., Barnett, A., McKinley, G. A., Gloege, L., and Pilcher, D.: Phytoplankton size impact on export flux in the global ocean, Global Biogeochem. Cy., 30, 1542-1562, https://doi.org/10.1002/2015GB005355, 2016b.

Najjar, R. G., Jin, X., Louanchi, F., Aumont, O., Caldeira, K., Doney, S. C., Dutay, J.-C., Follows, M., Gruber, N., Joos, F., Lindsay, K., Maier-Reimer, E., Matear, R. J., Matsumoto, K., Monfray, P., Mouchet, A., Orr, J. C., Plattner, G.-K., Sarmiento, J. L., Schlitzer, R., Slater, R. D., Weirig, M.-F., Yamanaka, Y., and Yool, A.: Impact of circulation on export production, dissolved organic matter, and dissolved oxygen in the ocean: Results from Phase II of the Ocean Carbon-cycle Model Intercomparison Project (OCMIP-2), Global Biogeochem. Cycles, 21, 1-22, https://doi.org/10.1029/2006GB002857, 2007.

Nagelkerken, I. and Connell, S. D.: Global alteration of ocean ecosystem functioning due to increasing human $\mathrm{CO}_{2}$ emissions, Proc. Natl. Acad. Sci. USA, 112, 13272-13277, https://doi.org/10.1073/pnas.1510856112, 2015. 
Niemeyer, D., Kemena, T. P., Meissner, K. J., and Oschlies, A.: A model study of warming-induced phosphorus-oxygen feedbacks in open-ocean oxygen minimum zones on millennial timescales, Earth Syst. Dynam., 8, 357-367, https://doi.org/10.5194/esd-8357-2017, 2017.

Niemeyer, D., Kriest, I., and Oschlies, A.: The effect of marine aggregate parameterisations on nutrients and oxygen minimum zones in a global biogeochemical model, Biogeosciences, 16, 3095-3111, https://doi.org/10.5194/bg-16-3095-2019, 2019.

Norris, R. D., Kirtland Turner, S., Hull, P. M., and Ridgwell, A.: Marine ecosystem responses to Cenozoic global change, Science, 341, 492-498, https://doi.org/10.1126/science.1240543, 2013.

Olivarez Lyle, A. and Lyle, M. W.: Missing organic carbon in Eocene marine sediments: Is metabolism the biological feedback that maintains end-member climates?, Paleoceanography, 21, 113, https://doi.org/10.1029/2005PA001230, 2006.

Omand, M. M., Govindarajan, R., He, J., and Mahadevan, A.: Sinking flux of particulate organic matter in the oceans: Sensitivity to particle characteristics, Sci. Rep., 10, 1-16, https://doi.org/10.1038/s41598-020-60424-5, 2020.

Palmer, J. R. and Totterdell, I. J.: Production and export in a global ocean ecosystem model, Deep Sea Res. Part I Oceanogr. Res. Pap., 48, 1169-1198, https://doi.org/10.1016/S09670637(00)00080-7, 2001.

Pasquier, B. and Holzer, M.: The plumbing of the global biological pump: Efficiency control through leaks, pathways, and time scales, J. Geophys. Res.-Oceans, 121, 6367-6388, https://doi.org/10.1002/2016JC011821, 2016.

Pershing, A. J., Christensen, L. B., Record, N. R., Sherwood, G. D., and Stetson, P. B.: The impact of whaling on the ocean carbon cycle: Why bigger was better, PLoS One, 5, 1-9, https://doi.org/10.1371/journal.pone.0012444, 2010.

Pomeroy, L. R. and Wiebe, W. J.: Temperature and substrates as interactive limiting factors for marine heterotrophic bacteria, Aquat. Microb. Ecol., 23, 187-204, https://doi.org/10.3354/ame023187, 2001.

Quere, C. Le, Harrison, S. P., Colin Prentice, I., Buitenhuis, E. T., Aumont, O., Bopp, L., Claustre, H., Cotrim Da Cunha, L., Geider, R., Giraud, X., Klaas, C., Kohfeld, K. E., Legendre, L., Manizza, M., Platt, T., Rivkin, R. B., Sathyendranath, S., Uitz, J., Watson, A. J., and Wolf-Gladrow, D.: Ecosystem dynamics based on plankton functional types for global ocean biogeochemistry models, Glob. Chang. Biol., 11, 2016-2040, https://doi.org/10.1111/j.1365-2486.2005.1004.x, 2005.

Raupach, M. R., Gloor, M., Sarmiento, J. L., Canadell, J. G., Frölicher, T. L., Gasser, T., Houghton, R. A., Le Quéré, C., and Trudinger, C. M.: The declining uptake rate of atmospheric $\mathrm{CO}_{2}$ by land and ocean sinks, Biogeosciences, 11, 3453-3475, https://doi.org/10.5194/bg-11-3453-2014, 2014.

Redfield, A. C.: On the proportions of organic derivatives in sea water and their relation to the composition of plankton, James Johnstone Meml. Vol., 176, 176-192, 1934.

Regaudie-De-Gioux, A. and Duarte, C. M.: Temperature dependence of planktonic metabolism in the ocean, Global Biogeochem. Cy., 26, 1-10, https://doi.org/10.1029/2010GB003907, 2012.

Richardson, K. and Bendtsen, J.: Photosynthetic oxygen production in a warmer ocean: the Sargasso Sea as a case study, Philos. T. Roy. Soc. A, 375, 20160329, https://doi.org/10.1098/rsta.2016.0329, 2017.

Richardson, K. and Bendtsen, J.: Vertical distribution of phytoplankton and primary production in relation to nutricline depth in the open ocean, Mar. Ecol. Prog. Ser., 620, 33-46, https://doi.org/10.3354/meps12960, 2019.

Ridgwell, A. J.: seao2.info: cGENIE.muffin Earth system model resources, available at: https://www.seao2.info/mymuffin.html, last access 12 July 2021.

Ridgwell, A., Hargreaves, J. C., Edwards, N. R., Annan, J. D., Lenton, T. M., Marsh, R., Yool, A., and Watson, A.: Marine geochemical data assimilation in an efficient Earth System Model of global biogeochemical cycling, Biogeosciences, 4, 87-104, https://doi.org/10.5194/bg-4-87-2007, 2007.

Ridgwell, A. J. and Schmidt, D. N.: Past constraints on the vulnerability of marine calcifiers to massive carbon dioxide release, Nat. Geosci., 3, 196-200, https://doi.org/10.1038/ngeo755, 2010.

Ridgwell, A., Reinhard, C., van de Velde, S., Adloff, M., DomHu, Wilson, J., Ward, B., Monteiro, F., and Vervoort, P.: derpycode/cgenie.muffin: Crichton et al. [revised for GMD], Zenodo, https://doi.org/10.5281/zenodo.3999080, 2020a.

Ridgwell, A., DomHu, Peterson, C., Ward, B., sjszas, evansmn, and Jones, R.: derpycode/muffindoc: Crichton et al. [2020] (GMD) (version v0.9.13), Zenodo, https://doi.org/10.5281/zenodo.4305997, 2020 b.

Riebesell, U., Schulz, K. G., Bellerby, R. G. J., Botros, M., Fritsche, P., Meyerhöfer, M., Neill, C., Nondal, G., Oschlies, A., Wohlers, J., and Zöllner, E.: Enhanced biological carbon consumption in a high $\mathrm{CO}_{2}$ ocean, Nature, 450, 545-548, https://doi.org/10.1038/nature06267, 2007.

Riebesell, U., Kortzinger, A., and Oschlies, A.: Sensitivities of marine carbon fluxes to ocean change, Proc. Natl. Acad. Sci., 106, 20602-20609, https://doi.org/10.1073/pnas.0813291106, 2009.

Sarmento, H., Montoya, J. M., Vázquez-Domínguez, E., Vaqué, D., and Gasol, J. M.: Warming effects on marine microbial food web processes: How far can we go when it comes to predictions?, Philos. T. Roy. Soc. B, 365, 2137-2149, https://doi.org/10.1098/rstb.2010.0045, 2010.

Sarmiento, J. L., Slater, R., Barber, R., Bopp, L., Doney, S. C., Hirst, A. C., Kleypas, J., Matear, R., Mikolajewicz, U., Monfray, P., Soldatov, V., Spall, S. A., and Stouffer, R.: Response of ocean ecosystems to climate warming, Global Biogeochem. Cy., 18, 123, https://doi.org/10.1029/2003GB002134, 2004.

Sauerland, V., Kriest, I., Oschlies, A., and Srivastav, A.: Multiobjective Calibration of a Global Biogeochemical Ocean Model Against Nutrients, Oxygen, and Oxygen Minimum Zones, J. Adv. Model. Earth Sy., 11, 1285-1308, https://doi.org/10.1029/2018MS001510, 2019.

Schartau, M., Wallhead, P., Hemmings, J., Löptien, U., Kriest, I., Krishna, S., Ward, B. A., Slawig, T., and Oschlies, A.: Reviews and syntheses: parameter identification in marine planktonic ecosystem modelling, Biogeosciences, 14, 1647-1701, https://doi.org/10.5194/bg-14-1647-2017, 2017.

Schmittner, A., Oschlies, A., Giraud, X., Eby, M., and Simmons, H. L.: A global model of the marine ecosystem for long-term simulations: Sensitivity to ocean mixing, buoyancy forcing, particle sinking, and dissolved organic matter cycling, Global Biogeochem. Cycles, 19, 1-17, https://doi.org/10.1029/2004GB002283, 2005. 
Schwinger, J., Tjiputra, J. F., Heinze, C., Bopp, L., Christian, J. R., Gehlen, M., Ilyina, T., Jones, C. D., Salas-Mélia, D., Segschneider, J., Séférian, R., and Totterdell, I.: Nonlinearity of ocean carbon cycle feedbacks in CMIP5 earth system models, J. Climate, 27, 3869-3888, https://doi.org/10.1175/JCLI-D-1300452.1, 2014.

Séférian, R., Berthet, S., Yool, A., Palmiéri, J., Bopp, L., Tagliabue, A., Kwiatkowski, L., Aumont, O., Christian, J., Dunne, J., Gehlen, M., Ilyina, T., John, J. G., Li, H., Long, M. C., Luo, J. Y., Nakano, H., Romanou, A., Schwinger, J., Stock, C., Santana-Falcón, Y., Takano, Y., Tjiputra, J., Tsujino, H., Watanabe, M., Wu, T., Wu, F., and Yamamoto, A.: Tracking Improvement in Simulated Marine Biogeochemistry Between CMIP5 and CMIP6, Curr. Clim. Chang. Reports, 6, 95-119, https://doi.org/10.1007/s40641-020-00160-0, 2020.

Segschneider, J. and Bendtsen, J.: Temperature-dependent remineralization in a warming ocean increases surface pCO2 through changes in marine ecosystem composition, Global Biogeochem. Cy., 27, 1214-1225, https://doi.org/10.1002/2013GB004684, 2013.

Shimoda, Y. and Arhonditsis, G. B.: Phytoplankton functional type modelling: Running before we can walk? A critical evaluation of the current state of knowledge, Ecol. Model., 320, 29-43, https://doi.org/10.1016/j.ecolmodel.2015.08.029, 2016.

Sinha, B., Buitenhuis, E. T., Le Quéré, C., and Anderson, T. R.: Comparison of the emergent behavior of a complex ecosystem model in two ocean general circulation models, Prog. Oceanogr., 84, 204-224, https://doi.org/10.1016/j.pocean.2009.10.003, 2010 .

Somes, C. J., Landolfi, A., Koeve, W., and Oschlies, A.: Limited impact of atmospheric nitrogen deposition on marine productivity due to biogeochemical feedbacks in a global ocean model, Geophys. Res. Lett., 43, 4500-4509, https://doi.org/10.1002/2016GL068335, 2016.

Steffen, W., Rockström, J., Richardson, K., Lenton, T. M., Folke, C., Liverman, D., Summerhayes, C. P., Barnosky, A. D., Cornell, S. E., Crucifix, M., Donges, J. F., Fetzer, I., Lade, S. J., Scheffer, M., Winkelmann, R., and Schellnhuber, H. J.: Trajectories of the Earth System in the Anthropocene, Proc. Natl. Acad. Sci. USA, 115, 8252-8259, https://doi.org/10.1073/pnas.1810141115, 2018.

Stramma, L., Johnson, G. C., Sprintall, J., and Mohrholz, V.: Expanding oxygen-minimum zones in the tropical oceans, Science, 320, 655-658, https://doi.org/10.1126/science.1153847, 2008.

Tagliabue, A., Bopp, L., and Gehlen, M.: The response of marine carbon and nutrient cycles to ocean acidification: Large uncertainties related to phytoplankton physiological assumptions, Global Biogeochem. Cy., 25, 1-13, https://doi.org/10.1029/2010GB003929, 2011.

Tagliabue, A., Aumont, O., DeAth, R., Dunne, J. P., Dutkiewicz, S., Galbraith, E., Misumi, K., Moore, J. K., Ridgwell, A., Sherman, E., Stock, C., Vichi, M., Völker, C., and Yool, A.: How well do global ocean biogeochemistry models simulate dissolved iron distributions?, Global Biogeochem. Cy., 30, 149174, https://doi.org/10.1002/2015GB005289, 2016.

Taucher, J. and Oschlies, A.: Can we predict the direction of marine primary production change under global warming?, Geophys. Res. Lett., 38, 1-6, https://doi.org/10.1029/2010GL045934, 2011.
Tjiputra, J. F., Roelandt, C., Bentsen, M., Lawrence, D. M., Lorentzen, T., Schwinger, J., Seland, Ø., and Heinze, C.: Evaluation of the carbon cycle components in the Norwegian Earth System Model (NorESM), Geosci. Model Dev., 6, 301-325, https://doi.org/10.5194/gmd-6-301-2013, 2013.

Volodin, E. M.: Atmosphere-ocean general circulation model with the carbon cycle, Izv. Atmos. Ocean. Phys., 43, 266-280, https://doi.org/10.1134/S0001433807030024, 2007.

Ward, B. A., Dutkiewicz, S., and Follows, M. J.: Modelling spatial and temporal patterns in size-structured marine plankton communities: top-down and bottom-up controls, J. Plankton Res., 36, 31-47, https://doi.org/10.1093/plankt/fbt097, 2014.

Ward, B. A., Wilson, J. D., Death, R. M., Monteiro, F. M., Yool, A., and Ridgwell, A.: EcoGEnIE 1.0: plankton ecology in the cGEnIE Earth system model, Geosci. Model Dev., 11, 4241-4267, https://doi.org/10.5194/gmd-11-4241-2018, 2018.

Watanabe, S., Hajima, T., Sudo, K., Nagashima, T., Takemura, T., Okajima, H., Nozawa, T., Kawase, H., Abe, M., Yokohata, T., Ise, T., Sato, H., Kato, E., Takata, K., Emori, S., and Kawamiya, M.: MIROC-ESM 2010: model description and basic results of CMIP5-20c3m experiments, Geosci. Model Dev., 4, 845-872, https://doi.org/10.5194/gmd-4-845-2011, 2011.

Watson, A. J.: Oceans on the edge of anoxia, Science, 354, 15291530, https://doi.org/10.1126/science.aaj2321, 2016.

Weber, T., Cram, J. A., Leung, S. W., DeVries, T. and Deutsch, C.: Deep ocean nutrients imply large latitudinal variation in particle transfer efficiency, Proc. Natl. Acad. Sci. USA, 113, 8606-8611, https://doi.org/10.1073/pnas.1604414113, 2016.

Wilson, J. D., Barker, S., and Ridgwell, A.: Assessment of the spatial variability in particulate organic matter and mineral sinking fluxes in the ocean interior: Implications for the ballast hypothesis, Global Biogeochem. Cy., 26, 1-15, https://doi.org/10.1029/2012GB004398, 2012.

Wilson, J. D., Monteiro, F., Schmidt, D. N., Ward, B. A., and Ridgwell, A.: Linking marine plankton ecosystems and climate: A new modelling approach to the warm Early Eocene climate., Paleoceanogr. Paleoclimatology, 33, 14391452, https://doi.org/10.1029/2018PA003374, 2018.

Wu, T., Song, L., Li, W., Wang, Z., Zhang, H., Xin, X., Zhang, Y., Zhang, L., Li, J., Wu, F., Liu, Y., Zhang, F., Shi, X., Chu, M., Zhang, J., Fang, Y., Wang, F., Lu, Y., Liu, X., Wei, M., Liu, Q., Zhou, W., Dong, M., Zhao, Q., Ji, J., Li, L., and Zhou, M.: An overview of BCC climate system model development and application for climate change studies, Acta Meteorol. Sin., 28, 34 56, https://doi.org/10.1007/s13351-014-3041-7, 2014.

Yao, W., Kvale, K. F., Achterberg, E., Koeve, W., and Oschlies, A.: Hierarchy of calibrated global models reveals improved distributions and fluxes of biogeochemical tracers in models with explicit representation of iron, Environ. Res. Lett., 14, https://doi.org/10.1088/1748-9326/ab4c52, 2019.

Zeebe, R. E. and Wolf-Gladrow, D.: $\mathrm{CO}_{2}$ in seawater: Equilibrium, kinetics, isotopes, Elsevier Oceanography Series, 65, Amsterdam, 2001. 